\title{
THE USE OF INFORMATION AND COMMUNICATION TECHNOLOGIES BY ENTERPRISES IN THE EUROPEAN UNION MEMBER COUNTRIES
}

\author{
Aleksandra Zecevic ${ }^{*_{1}}$, Jelena Radovic Stojanovic ${ }^{2}$ and Aleksandar Cudan ${ }^{2}$ \\ ${ }^{1}$ Faculty of Economics, University of Belgrade, Belgrade, The Republic of Serbia \\ ${ }^{2}$ The Academy of Criminalistic and Police Studies, Department of Criminalistics, Belgrade
}

The paper analyzes the use of information and communication technologies (ICT) in enterprises in the European Union member states. The objectives of the analysis were to examine the level reached in the application of ICT in European enterprises and explore the differences in ICT usage that exist between the EU member states. The analysis is based on the Eurostat data on ICT usage in enterprises in the European Union countries (EU-28) for the years 2018 and 2017. The following indicators of ICT usage were analyzed: fixed broadband access, the speed of the internet connections, the presence of the Internet (enterprises having a website), the use of social media, the use of cloud computing services, e-commerce indicators (the share of the enterprises making e-sales and the share of e-commerce in the total turnover) and the indicators of e-business integration - the share of the enterprises using enterprise resource planning $(\mathrm{ERP})$, customer relationship management (CRM) and the supply chain management (SCM) software applications. A comparative analysis of the EU countries by the value of these indicators was carried out. The main focus in the analysis was to identify the factors that influence the difference in the value of the ICT indicators between the countries. The analysis has shown that the regional position, the geographic characteristics, the size of the country and the level of its economic development are the factors that influence these differences.

Keywords: information and communication technology, e-commerce, e-business integration indicators, enterprises, European Union

\section{JEL Classification: 0330, L86}

\section{INTRODUCTION}

Despite the great attention being paid to the implementation and development of information and

* Correspondence to: A. Zecevic, Faculty of Economics, University of Belgrade, Kamenicka 6, 11000 Belgrade, The Republic of Serbia; e-mail: azecevic@ekof.bg.ac.rs communication technology (ICT) in the EU countries and the importance given to it in the public, the media and science, there are still IT-related topics, even entire fields, which are insufficiently dealt with. This is especially true when it comes to its usage in enterprises. This paper deals with one of these, not yet sufficiently researched topic, and analyzes the level 
achieved in the use of information and communication technologies in enterprises in European countries. Although there is a general opinion that, due to their economic development, the EU countries have come a long way in implementing ICT, there are still significant differences between them in this respect. The aim of the study was to analyze the achieved level in the use of ICT in enterprises in the EU countries, explore the differences and identify the factors that influence the use of ICT in enterprises. Of course, Europe, i.e. European institutions, primarily the European Commission and Eurostat, deal with these issues; in their analyses, however, they mainly focus on the member states individually. The subject matter of this paper is the identification of regularities, synthesizing the findings regarding the factors that influence the use of ICT in enterprises in general, rather than an analysis of only one individual country or a single group of countries within the European Union.

As the EU member states significantly differ in their characteristics (in terms of their population, surface area, geographic position, historical and cultural heritage, the structure of their economies, the achieved level of social and economic development, the level of technical and technological development, and so on), the research study rests on the hypothesis that the differences between the member states, which reflect on all the aspects of their economic and social life, have an impact on the adoption and application of information and communication technologies. The question that arises is: What are the differences, i.e. what are the characteristics of the countries that influence the use of ICT, in particular the use of ICT in enterprises? In order to answer this question, the statistical indicators of the use of information and communication technologies in enterprises collected and published by EUROSTAT are observed, and a comparative analysis among the countries based on the value of these indicators was carried out.

At the beginning of this paper, a review of the literature dealing with the usage of ICT in enterprises in the European Union is provided. Then, Eurostat's methodology used to collect the data and calculate the indicators of ICT usage in enterprises is presented in brief. The central part of the paper is dedicated to the description of the analysis of the selected indicators and the comparative analysis between the countries in order to point out the factors that influence the differences in the value of the indicators between the countries. In the conclusion, the main results of the analysis are summarized. Finally, the appendix provides the tables showing the ranking of the EU member states by the indicator values.

\section{LITERATURE REVIEW}

That the studies dealing with the economic aspects of the ICT implementation focus on a relatively small number of topics was observed as early as in 2015 (Roztocki \& Weistroffer, 2015). To date, not much has changed; so, studies mostly deal with the following topics: the impact of ICT on the way enterprises do business and their efficiency and competitiveness growth (Real, Leal \& Roldán, 2006), the impact of ICT on economic growth and development (Stankic, Jovanovic Gavrilovic \& Soldic Aleksic, 2018), the economy and society as a whole (Roztocki, Soja \& Weistroffer, 2019). If, as in (Bouwman, van der Hooff, van der Wijngaert \& van Dijk, 2005), adoption, implementation, application and effects are analyzed when ICT usage in organizations is concerned, studies could be said to be dealing mainly with the effects of ICT on enterprises' operations, while ICT implementation and application in enterprises are insufficiently addressed, as is evidenced by a small number of papers. The adoption of advanced IC technology, such as cloud computing and big data analytics, has been in the focus of researchers' attention lately (for the most important characteristics and concepts of big data, see Chroneos-Krasavac, Soldic-Aleksic \& Petkovic, 2016).

Regarding the studies dealing with ICT usage in the EU countries, the most important source of data is the European Commission. Each year, the European Commission releases the European Digital Progress Report (EDPR) for all the EU countries, which includes a digital profile of each country (Country Profile). In 
that document, the progress of the EU member states in digitalization is evaluated. The evaluation uses the value of the Digital Economy and Society Index (DESI) for the country, combined with a qualitative analysis (European Commission, 2017). The Digital Economy and Society Index (DESI) is a composite index published by the European Commission, which quantifies progress in digitization (European Commission, 2019). Qualitative analysis includes an analysis of country-specific conditions and policies. The evaluation of the ICT implementation level for each country avoids value judgments (e.g. developed/ underdeveloped), dividing countries into medium-, high- and low-performing countries. For example, the countries that are DESI-rated at the average level are medium-performing countries; those being above the average are referred to as high-performing, whereas those below the average are low-performing countries. One major part of the Digital Progress Report, entitled the Digitalization of Enterprises, refers to the use of ICT in enterprises.

The Digital Progress Report is very detailed and contains a lot of data. The European Commission also publishes a large number of analyses and studies dealing with ICT application in European economies. On the other hand, there is not enough scientific work done in this field. Considering the expertise of the European Commission's reports and the abundance of published data, one might think that it is sufficient for the European Commission alone to deal with data, statistics and analyses. Apart from that expert perspective, however, there is a lack of the research initiative that is not solely related to European institutions. There is still plenty of room for research and every new aspect of the analysis and a different point of view could be helpful and give new insights.

Several studies dealing with ICT usage in enterprises in European countries have made efforts to rank the countries according to the level of the implementation achieved and identify the factors influencing the process of ICT adoption. J. Becker, A. Becker, P. Sulikowski and T. Zdziebko, (2018) rank the countries of Central Europe, the members of the European
Union (Austria, the Czech Republic, Germany, Hungary, Slovakia, and Slovenia) according to ICT usage in enterprises using the analytic network process (ANP). The survey shows that, among these countries, Slovenia and Austria are the 2017 leaders in ICT usage in enterprises. A. Zečević and J. Radović-Stojanović (2018), analyze the use of ICT in enterprises in Slovenia, Croatia, The Republic of Serbia, Bosnia and Herzegovina, Macedonia, and Montenegro. Investment in and the development of the information and communication infrastructure are identified as the factors influencing ICT usage in enterprises in these countries. The study concludes that the EU member states, namely Slovenia and Croatia, are leading in ICT usage in their enterprises, especially so in the adoption of advanced technology, i.e. cloud computing and e-commerce. The use of information and communication technologies in Serbian enterprises in comparison with the European average is presented in (Stankić \& Stojković, 2017).

The United Nations (UN), which ranks countries on the basis of the ICT Development Index (IDI), a composite index based on the 11 ICT indicators, also addresses the level of ICT implementation and country ranking. Based on the 2017 IDI Index, the best-ranked members of the European Union are Denmark, the United Kingdom, and the Netherlands (United Nations, 2018). J. Soldić-Aleksić and R. Stankić (2015), point to the Networked Readiness Index (NRI), a composite index calculated and published by the World Economic Forum. According to the Global Information Technology Report published by the organization, six European countries (Finland, Sweden, Norway, the Netherlands, Switzerland, and the United Kingdom) are among the 10 best-ranked countries by the NRI index value (World Economic Forum, 2016). The NRI structure is complex, as it consists of the 54 indicators of ICT application in the economy and society. Regarding the classification of the European countries by the success of ICT implementation on the basis of this index, it is regional, with the South, Central, and Eastern European countries seen to be lagging behind the countries of Northern and Central Europe. 


\section{DATA SOURCES AND METHODOLOGY}

Eurostat's data on ICT usage in enterprises are a result of the statistical survey called "Usage of informationcommunication technology (ICT) in enterprises". The survey has been conducted once a year since 2002 in all EU Member States. It collects data on the use of ICT in enterprises, the use of the Internet, e-business, and the other relevant aspects of ICT usage in enterprises. The results are published within the Digital Economy and Society statistical area on the Eurostat website. The results are published in Eurostat's publications, as well as in Eurostat's database.

The methodological basis of the survey is the Methodological Manual for Information Society Statistics (Eurostat, 2018). The Methodological Manual defines the observation units, the research objective, the research time period, the target population, the variables to be covered, the indicators to be calculated, the aggregates to be obtained, the sampling system, the concepts, the nomenclatures, and all the other elements of the statistical survey. The common survey methodology has contributed to the comparability of the data obtained from all the EU countries. The survey based on this methodology is also being conducted in the other European states that are not the EU members.

The observation units, i.e. reporting units, in the survey are enterprises with 10 or more employees small (10-49), medium (50-249), and large enterprises (enterprises with more than 250 employees). The survey is conducted on the basis of a questionnaire containing the questions grouped by several modules, these modules being: Computer Application, ICT Experts and Skills, Internet Access and Usage, Use of Cloud Computing Services, E-Commerce, Electronic Invoicing, Big Data Analytics. In the latest version of the methodology, the survey has been expanded with the following modules: Using a 3-D Printer and Using Robotics. The questionnaire is filled out in enterprises by phone or sent by e-mail. The data collected through the survey are submitted to the national statistical offices to process them, store them in a database, and publish them in official publications.
In this paper, fixed broadband access in enterprises, the speed of internet connections, the presence of the Internet (enterprises having a web site), the use of social media, the use of cloud computing services, e-commerce indicators (the share of the enterprises that make e-sales and the share of e-commerce in the total turnover) and the indicators of e-business integration (the share of the enterprises that use Enterprise Resource Planning (ERP), Customer Relationship Management (CRM) and the Supply Chain Management (SCM) software applications are analyzed. EUROSTAT collects numerous data and calculates a number of the other indicators of the usage of information and communication technologies in enterprises, and the indicators observed in this paper are chosen because they are the indicators that EUROSTAT itself singles out as representative and most commonly used in its analyses. Relying on the EUROSTAT indicators, a comparative analysis of the values of the selected indicators by country, on the one hand, and the characteristics of the countries, on the other, is carried out in order to identify the regularities, group the countries with the indicator values at approximately the same level and identify the factors that influence the usage of ICT in enterprises.

\section{ICT USAGE INDICATORS IN THE EUROPEAN UNION ENTERPRISES - EMPIRICAL DATA AND ANALYSIS}

In this paper, the data on the usage of ICT in enterprises in the European Union member states were used. The data were downloaded from the Eurostat Database. The analysis relies on the 2018 data, and where the 2018 data have not been published yet, the latest available data, i.e. the 2017 data, were used.

In 2018, 92\% of the enterprises in European Union used fixed broadband Internet access. A share of 90\% was reached in 2012, and has not changed much since then, ranging from $92 \%$ to $93 \%$ from year to year (Figure 1). The share of the enterprises using a fixed broadband Internet connection is the indicator of the development of the information infrastructure, 
and ranges from $81 \%$ of the enterprises in Latvia to $100 \%$ in Denmark. Belgium $(96 \%)$, the Netherlands (99\%) and Luxembourg (97\%) have a high share of enterprises, whereas the major European economies, i.e. Germany (93\%), France (94\%), Italy (91\%), and Spain $(91 \%)$ recorded an average share. The countries with the share of enterprises using a fixed broadband connection below $90 \%$ are Romania (82\%), Hungary (83\%), Bulgaria (84\%), Poland (87\%), Slovakia (89\%), the Czech Republic (89\%), and Greece (84\%). With the exception of Greece, these are Central and Eastern European countries. Greece is a coastal country, with a long, rugged coastline and a large number of islands and peninsulas, which dictates certain specific features regarding the development of the IT infrastructure. As the paper will show, there are also the other indicators that are common to individual coastal and island countries.

The basic form of the Internet presence pertains to enterprises having a website. Enterprises use their website to describe their goods or services, show prices, introduce customers to products, include links to social networks, enable online orders and track such orders. In 2018, 77\% of the enterprises in the European Union had their own website, and since 2012 , that share has increased by $6 \%$ (Figure 1 ). The following countries have demonstrated a share of the enterprises having their own website higher than 90\%: Sweden (92\%), Finland (96\%), Denmark $(96 \%)$, as well as the Benelux countries - Belgium (84\%), the Netherlands (94\%) and Luxembourg (83\%). The large, developed European economies, such as Germany (87\%) and the United Kingdom (82\%), as well as the Czech Republic (83\%), have a high share of the enterprises with their own website, whereas France $(69 \%)$, Italy $(71 \%)$ and Spain $(76 \%)$ have shown a share of the enterprises that have a website of their own below the European average. The lowest share of the enterprises having a website of their own is found in Latvia (63\%), Romania (44\%), Bulgaria (51\%) and Hungary $(66 \%)$.

Another important indicator of the infrastructure development is the speed of the Internet connection. In 2018, 20\% of the EU-28 enterprises had an Internet connection speed ranging from 2 to $10 \mathrm{Mb} / \mathrm{s}, 24 \%$ of the enterprises were within the range from 10 to 30 $\mathrm{Mb} / \mathrm{s}$, and $25 \%$ of the enterprises were within the range from 30 to $100 \mathrm{Mb} / \mathrm{s}$, with a connection speed greater than $100 \mathrm{Mb} / \mathrm{s}$ in 18\% of the enterprises (Figure 2 ). The share of the enterprises that use a slower Internet connection has been declining for the past five years, while the share of the enterprises that use a higher connection speed has been increasing. This trend is present in most countries, regardless of the enterprise structure in terms of the connection speed.

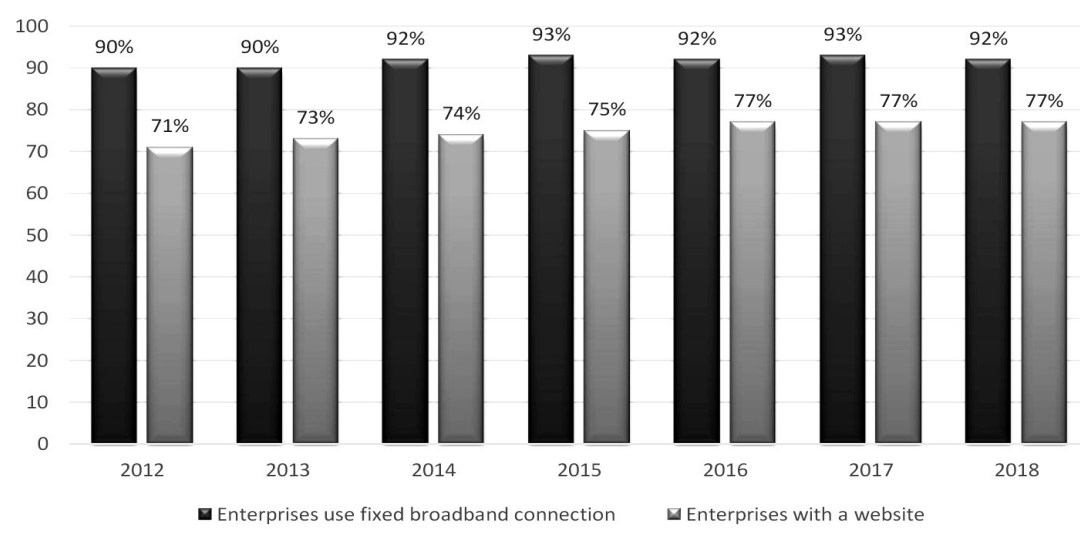

Figure 1 The enterprises using a broadband internet connection and the enterprises having a website of their own, EU-28, 2012-2018 (\% of the enterprises) 
One of the most important aspects of using the Internet in enterprises pertains to the use of social media. The types of social media are: social networks, multimedia content sharing sites (Youtube, Flickr, Picassa), the enterprises blog (Twitter), and wiki data sources. In several European countries, more than $50 \%$ of the enterprises used social media in 2017 (Finland - 63\%, Sweden - 65\%, the Netherlands - 68\%, Belgium - 58\%, Luxembourg - 54\%), whereas in the others, the share of these enterprises was around or even below 30\% (Bulgaria - 34\%, Romania - 35\%, Hungary - 38\%, Poland - 27\%, the Czech Republic $36 \%$, Slovakia - 39\%).

How social media are used by enterprises and how many enterprises use social media is best seen when using social networks. The smaller the country, the farther away from large European markets, the harder it is to reach and interact with customers on these markets, the greater is the share of the enterprises that use social networks in their operations. Thus, the largest share of the enterprises using social networks in 2017 is found in small island countries - Malta (73\%), Ireland (67\%), Cyprus (65\%), as well as Denmark (67\%), the Netherlands (66\%), Sweden (63\%), as well as in the United Kingdom, where the share of the enterprises using social networks is $60 \%$. All these countries have a share of the enterprises that use social networks higher than the average of $45 \%$ for the European Union as a whole. At the same time, enterprises in large European economies, in Central European countries, do not rely that much on social networks in their business doing, for which reason the share of the enterprises using social networks in these countries is below the EU-28 average and is 39\% in France, $40 \%$ in Germany, $42 \%$ in Italy, and slightly above the European average - 49\%, in Spain. Enterprises in these economies have other ways to reach customers and the common European market; moreover, they make up that market (or at least most of it).

The lowest share of the enterprises using social networks in their business doing is recorded in Hungary (36\%), Slovakia (35\%), Bulgaria $(34 \%)$, the Czech Republic (34\%), Romania (34\%), Latvia (29\%), and Poland (26\%). Again, these are Central and Eastern European countries, the former countries in the process of transition to the market economy. N. Roztocki and H. R. Weistroffer (2008), said that the social and economic characteristics of these countries and the level of economic development and business culture would reflect on the adoption and application of ICT. From the IT infrastructure, via the Internet usage and a website ownership, to communication with customers via social networks, these countries are still lagging behind developed European economies. P. Soja and P. R. Cunha (2015) summarize

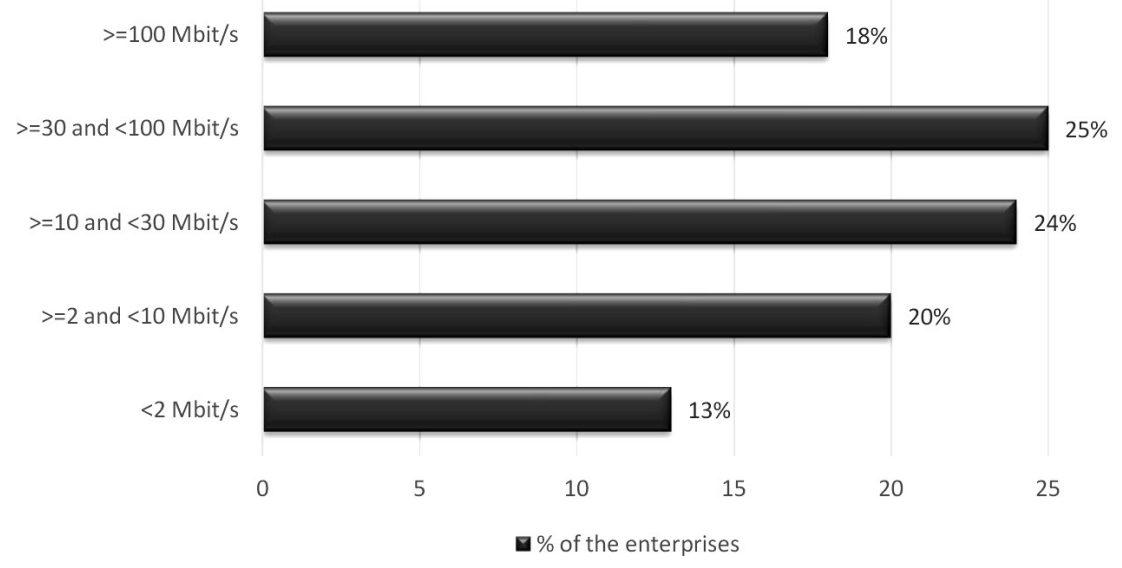

Figure 2 The Internet connection speed in the EU-28 enterprises, 2018. 
the characteristics of ICT implementation in these countries: a lack of a long-term strategic framework for ICT implementation, a low level of ICT usage, the need for foreign support in ICT adoption, the impact of foreign investment on ICT, an inadequate customer orientation, inadequate planning, limited resources, problems in education and the acceptance of ICT by employees.

Cloud computing services are different types of the ICT services accessed via the Internet, for example, email services, the storage of files, office software (Word, Excel), enterprise database hosting, financial or accounting software applications, the use of customer relationship management software (Customer Relationship Management - CRM), increasing the computer capacity to run enterprise software (Figure 3). At the EU-28 level in 2018, 26\% of the enterprises used cloud computing services. Norway (51\%), Sweden (57\%) and Finland (65\%) led in the use of these services, whereas Bulgaria (8\%), Romania (10\%) and Poland (11\%) had the lowest share of the enterprises using cloud computing services. Slovakia $(21 \%)$ and Hungary $(18 \%)$ are slightly closer to the European average. Large European economies, France $(19 \%)$, Germany (22\%), Spain $(22 \%)$ and Italy (23\%) are below the European average, whereas small economies and island countries, such as Ireland (45\% of the enterprises), Malta (37\% of the enterprises) and Croatia (31\%) seek to improve their IT performances by using cloud services.

As with the use of social networks, it is shown once again, and this time on the example of cloud computing, that the size of a country may not be crucial in terms of adopting new technology and the implementation of ICT (Figure 4). Small European countries are also achieving significant results in implementing ICT (Zečević \& Radović-Stojanović, 2017).

Eurostat has been collecting e-commerce indicators since 2010, when the first e-commerce data in the Eurostat Database appeared. The level achieved in e-commerce development in the countries will be analyzed on the basis of the share of the enterprises selling their products online and the share of e-commerce in the total turnover of the enterprises. Online sales involve receiving orders using the methods specifically designed for receiving orders, such as Electronic Data Interchange (EDI), the website, or special applications (orders received via e-mail are not included) (Eurostat, 2018). The Internet sales indicator in the Eurostat Database is the share of the enterprises receiving electronic orders (Figure 5).

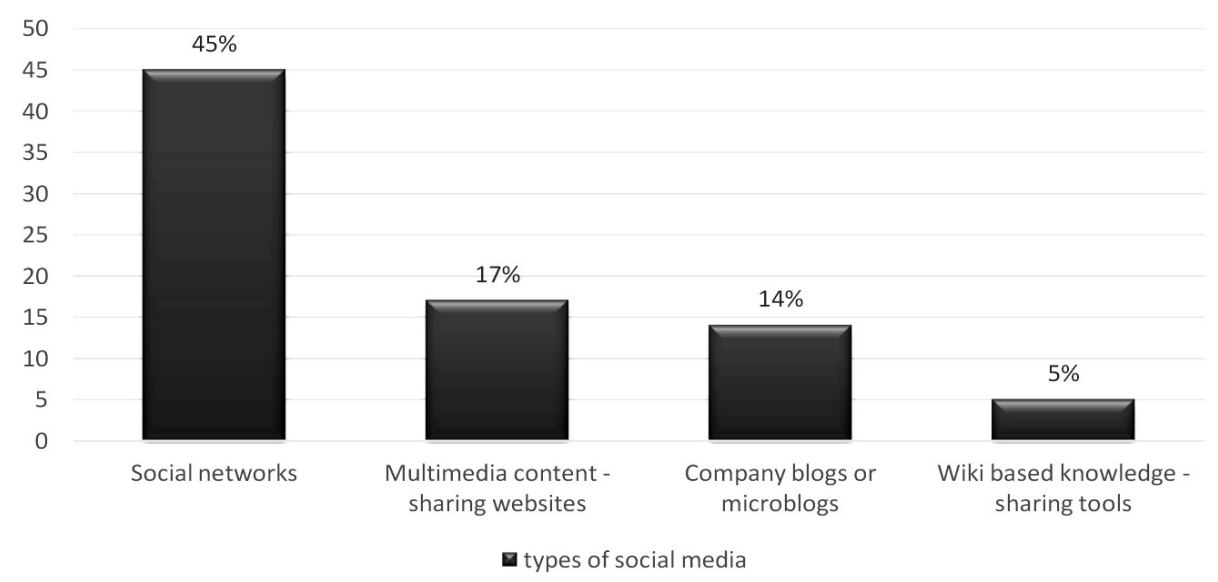

Figure 3 The use of social media in the EU-28 countries, 2017 (\% of the enterprises) 


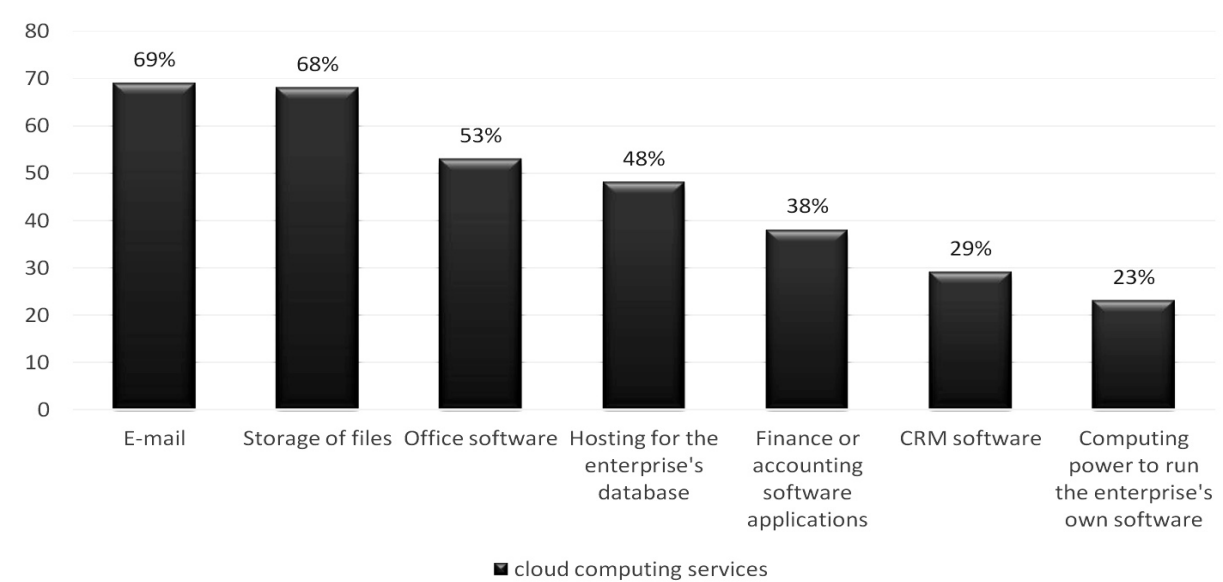

Figure 4 Cloud computing services in the European countries, EU-28, 2017 (\% of the enterprises)

Source: Authors

In $2018,20 \%$ of the enterprises in the EU-28 countries sold their products online. The share of online sales in the total turnover of the enterprises was $17 \%$. E-commerce has grown in recent years in almost all European Union countries, with the largest share of the enterprises selling electronically being in the Scandinavian countries, i.e. in Denmark (32\%), Norway $(29 \%)$ and Sweden $(32 \%)$, as well as in the Benelux countries, i.e. in Belgium (30\%) and the Netherlands (27\%), though not in Luxembourg (only
$16 \%$ ). E-commerce is also developed in the island countries, i.e. in Iceland (29\%), Ireland (35\%) and Malta (22\%). As expected, Bulgaria (8\%), Latvia (13\%), Romania (9\%), Poland (14\%), Slovakia (16\%), Hungary $(15 \%)$, as well as Greece (12\%), are below the European average. The major European economies are generally around the EU-28 average, with the exception of Italy (only 14\%), so the share of the enterprises selling online in Germany is $22 \%$, in France $19 \%$, and in Spain 20\%.

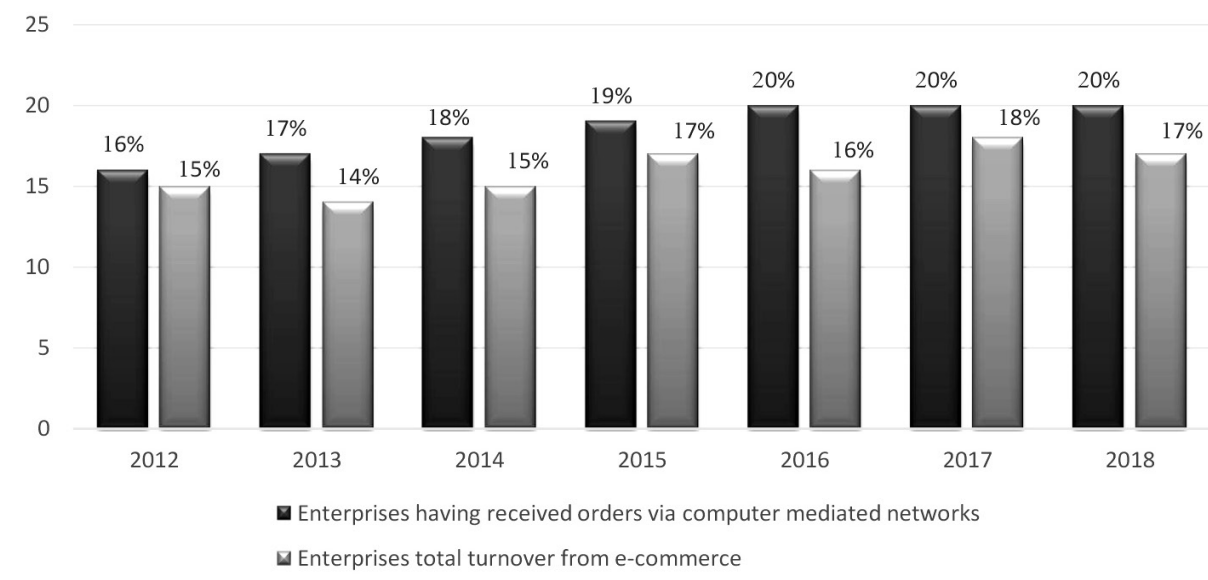

Figure 5 The share of the enterprises receiving electronic orders and the share of e-commerce in the total turnover, EU-28, 2012-2018 (\% of the enterprises) 
In some cases, a significant share of electronic turnover (online sales) is held by the enterprises in the countries that already have a large share of the enterprises selling online, such as Sweden (24\%), Denmark $(23 \%)$ and Finland $(21 \%)$, but it is also the case that the countries with a smaller share of the enterprises selling online make a large share of electronic turnover in the total turnover. For example, Slovakia, where only $16 \%$ of the enterprises sell electronically, has a $21 \%$ share of electronically generated turnover. On the other hand, the low share of electronically generated turnover is in the Netherlands (15\%) and Luxembourg (also 15\%) and in some large European economies as well, which would be expected to be quite the opposite since they already have a significant share of the enterprises selling online. For example, the share of electronically generated turnover in Germany is only 14\% and in Italy $11 \%$. The lowest share of electronically generated turnover is in Bulgaria (5\%), Latvia (6\%), Romania $(9 \%)$ and Poland $(15 \%)$.

E-business integration is monitored on the basis of the share of the enterprises using Enterprise Resource Planning (ERP), Customer Relationship Management (CRM), and the Supply Chain Management (SCM) software applications. ERP software integrates all departments and functions through a single IT system (or an integrated set of IT systems) in order to enable decision-making, encompassing all business operations (Zečević, 2015). CRM software integrates customer relationships, facilitates communication and business operations, and promotes sales through customer monitoring and supervision. SCM software manages information in the supply chain so as to improve supply and to better meet customer needs. The application of these pieces of software is an indicator of the degree of e-business integration in enterprises.

Seen at the EU-28 level in 2017, 34\% of the enterprises used ERP integrated business software; CRM software applications were used by $33 \%$ of the enterprises, and $18 \%$ of the enterprises created prerequisites for integrating with customers and managing the supply chain through the SCM software application. Considering that the Eurostat Database has only the 2017 data on CRM and SCM, Figure 6 only shows the share of the enterprises that use ERP software in the 2012-2017 period.

The use of ERP software is expected to highlight large, developed European economies, namely Germany (38\%), France (38\%), Italy $(37 \%)$, Spain $(46 \%$ of the enterprises), and ERP software is now used for e-business integration in some smaller countries as well, such as Greece (37\%) and Slovakia (31\%), which

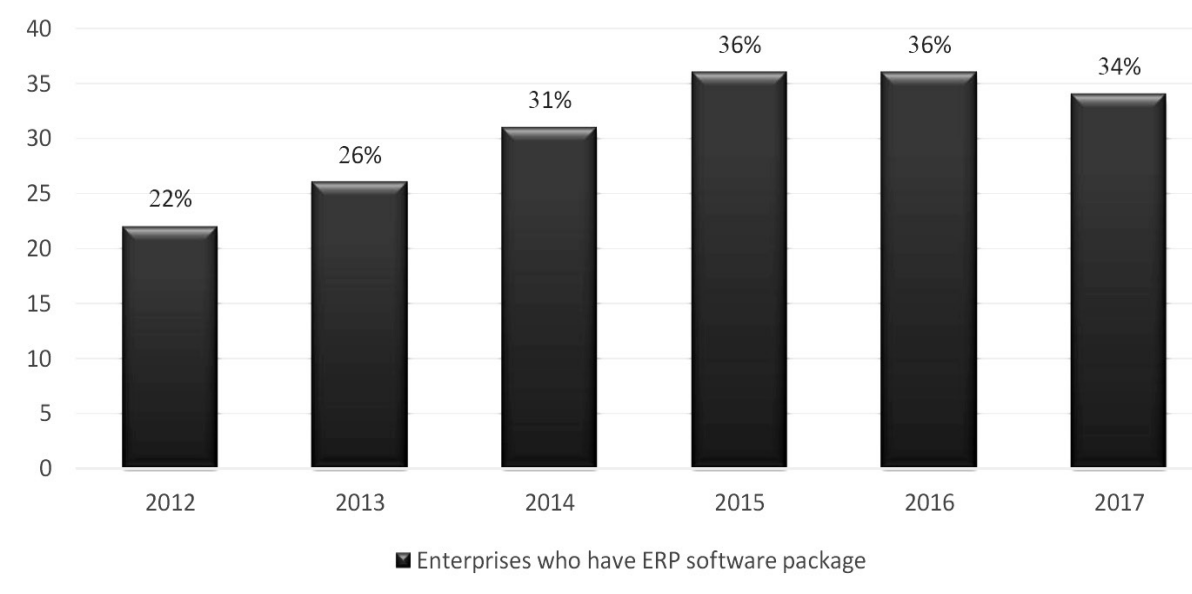

Figure 6 Using ERP software, EU-28, 2012-2017 (\% of the enterprises) 
do not stand out by the value of the other indicators observed. Hungary (14\%), Romania (17\%), Bulgaria (23\%), Poland (26\%), as well as Iceland (14\%), have a slightly lower share of the businesses using ERP software. In terms of using CRM software, Germany ( $46 \%$ of the enterprises) and Austria (43\%), as well as the Benelux countries - Belgium (42\%), Netherlands $(46 \%)$ and Luxembourg (39\%) - are in the lead, whereas Romania (13\%), Latvia (15\%), Hungary (13\%), Bulgaria and the Czech Republic (18\%) have only just begun to introduce CRM software. The case is similar with the use of SCM software, with Germany (30\%), Belgium (26\%), Finland (22\%), Lithuania (28\%) being ahead, whereas Hungary (9\%), Romania (7\%) and Latvia (6\%) are lagging behind in terms of SCM software.

\section{CONCLUSION}

The study has confirmed the research hypothesis that the differences between the member states have an impact on the level achieved in the adoption and implementation of information and communication technologies in enterprises in the EU countries. Comparing the values of ICT usage indicators, on the one hand, and the characteristics of the countries, on the other, the four factors that influence the usage of ICT in enterprises have been identified, namely: the regional position, the geographic characteristics, the size of the country and the level of the economic development achieved. The regional position of the countries determines the proximity of large markets and influences how companies communicate with customers. The geographic characteristics of the country may be an incentive for a better adoption and application of information technology in enterprises. The regional position and the geographic characteristics, however, may be the limiting factors in some cases, when the development of the ICT infrastructure is concerned. The size of the country is also important, but not as might be expected, in the sense that large, developed economies achieve the best performance in the implementation of ICT. On the contrary, small and dynamic European economies seek for development opportunities in ICT and often outperform large, developed economies by the value of ICT usage indicators. The level of the achieved economic development is an important factor because of the amount of investment in information technology, the development of information business culture and the willingness of enterprises to adopt information and communication technology. The level of development also influences the adoption of advanced information technology, such as cloud computing and e-business integration in enterprises. Additional research is needed to specify the impact of these four factors and for the possible identification of the other factors that affect the use of information and communication technologies in enterprises.

The regional grouping of the countries encountered in the literature (east/west, north/south) largely reflects a country's specifics and differences between countries, but the same needs to be more profiled and should be complemented by an analysis of the geographic characteristics of the countries. Therefore, there is still plenty of room for research, as regional generalizations are often not enough to make differences between the countries. The regional grouping of the countries needs to be further deepened by their geographic features and the level of the development achieved. A narrow classification of the countries is possible according to specific geographic features (e.g. island countries) or according to how they share the common economic history (Central and Eastern European countries, former transition countries) and economic and political interests (the Benelux countries, the Scandinavian countries). A more detailed analysis is needed to fully explore and appreciate the geographic specifics of the countries.

The level of the economic development of the countries is related to the development of the IT infrastructure and investment in ICT. The IT infrastructure is the basis of every ICT usage, so the countries with the low indicators of the infrastructure development often have the other indicators of ICT usage at a low level. However, some countries are still struggling to overcome their limitations in the infrastructure 
development. This is, for example, the case with some island countries, whose enterprises manage to communicate with customers through ICT and successfully integrate ICT into their businesses. This is also the case in some Central and Eastern European countries, whose enterprises, despite their modest infrastructure capacity, strive to keep their connection speeds above the average and use what they have at their disposal. In some cases, the infrastructure development constraints cannot be overcome, so the low value of the advanced technology indicators - the use of cloud computing and e-commerce services - is observed in the countries with lower IT infrastructure development indicators.

The Benelux countries, i.e. Belgium, the Netherlands and Luxembourg, have adopted new e-commercebased business and customer communication models and are leading the way in almost all the indicators. The situation is similar with the Scandinavian countries, which are above the European average in almost all of the observed indicators. Enterprises in small EU countries and the island countries are particularly leading in the use of social media, while in the Central and Eastern European countries the use of social networks and social media has not yet become an integral part of business. Regarding the use of ERP, SCM, and CRM software in enterprises, their use is still uneven across countries. These are technological solutions and ways of communication with customers that those enterprises have just started adopting both in the small and in the large European economies.

\section{REFERENCES}

Becker, J., Becker, A., Sulikowski, P., \& Zdziebko, T. (2018). ANP-based analysis of ICT usage in Central European enterprises. Paper presented at the 22nd International Conference on Knowledge-Based and Intelligent Information, \& Engineering Systems. Procedia Computer Science, 126, 2173-2183. doi.org/10.1016/j.procs.2018.07.231
Bouwman, H., van der Hooff, B., van der Wijngaert, L., \& van Dijk, J. (2005). Information and Communication Technology in Organizations: Adoption, Implementation, Use and Effects. Amsterdam, NI: Boom.

Chroneos-Krasavac, B., Soldic Aleksic, J., \& Petkovic, G. (2016). The big data phenomenon: The business and public impact. Industrija 44(2), 117-144. doi:10.5937/ industrija44-10036

European Commission. (2017). Europe's Digital Progress Report 2017. Brussels, 10.5.2017 SWD 160 final. Retrieved March 17, 2019, from htt://ec.europa.eu/digital-singlemarket/en/news/europes-digital-progress-report-2017

European Commission. (2019). Digital Economy and Society Index Report 2019 Connectivity. Retrieved May 14, 2019, from $h t t p: / / e c . e u r o p a . e u / d i g i t a l-s i n g l e-m a r k e t / e n / n e w s /$ digital-economy-and-society-index-desi-2019

Eurostat. (2018). ICT usage and e-commerce in enterprises, Methodological Manual for statistics on the Information Society. Retrieved April 05, 2019, from http://circabc. europa.eu/faces/jsp/extension/wai/navigation/container. jsp

Real, J. C., Leal, A., \& Roldán, J. L. (2006). Information technology as a determinant oforganizational learning and technological distinctive competencies. Industrial Marketing Management, 35, 505-521. doi:10.1016/j. indmarman.2005.05.004

Roztocki, N., \& Weistroffer, H. R. (2008). Information Technology in Transition Economies. Journal of Global Information Technology Management, 11(4), 2-9. doi:10.1080 /1097198x.2008.10856476

Roztocki, N., \& Weistroffer, H. R. (2015). Information and Communication Technology in Transition Economies: An Assessment of Research Trends. Information Technology for Development, 21(3), 330-364.

Roztocki, N., Soja, P., \& Weistroffer, H. R. (2019). The role of information and communication technologies in socioeconomic development: Towards a multidimensional framework. Information Technology for Development, 25(2), 171-183. doi.org/10.1080/02681102.2019 .1596654

Soja, P., \& Cunha, P. R. (2015). ICT in transition economies: Narrowing the research gap to developed countries. Information Technology for Development, 21(3), 323-329. doi/ full/10.1080/02681102.2015.1028734 
Soldić Aleksić, J., \& Stankić, R. (2015). A comparative analysis of Serbia and the EU member states in the context of networked readiness index values. Economic Annals, 60(206), 45-86. doi:10.2298/eka1506045S

Stankić, R., \& Stojković, D. (2017). The use of information and communication technologies in the business operations of Serbian enterprises. Ekonomske ideje i praksa, 27. doi:10.5937/EKOPRE1706393Z

Stankic, R., Jovanovic Gavrilovic, B., \& Soldic Aleksic, J. (2018). Information and communication technologies in education as a stimulus to economic development. Economic Horizons, 20(1), 59-71, doi:10.5937/ ekonhor1801061S

United Nation. (2018). Measuring the Information Society Report 2017 Volume 2. ICT country profiles. Retrieved May 17, 2019, from https://www.itu.int/en/ITU-D/Statistics/ Documents/publications/misr2017/MISR2017_Volume2.pdf
World Economic Forum. (2016). The Global Information Technology Report 2016. Retrieved April 20, 2019, from http://www3.weforum.org/docs/GITR2016/WEF_GITR_ Full_Report.pdf

Zečević, A. (2015.) Baze podataka u poslovanju. Beograd, RS: Zadužbina Andrejević.

Zečević, A., \& Radović Stojanović, J. (2017). The Use of Information and Communication Technologies in Enterprises in Serbia. Ekonomika preduzeća, 45(5-6), 393403. doi:10.5937/ekopre1706393z

Zečević, A., \& Radović Stojanović, J. (2018). The Use of Information and Communication Technologies in Enterprises in the Region: Level Achieved and Further Development. In S. Drezgić, S. Živković, \& M. Tomljanović (Eds.). Economics of Digital Transformation (pp. 177-194). Rijeka, Croatia: University of Rijeka, Faculty of Economics and Business in Rijeka.

Received on $7^{\text {th }}$ August 2019, after revision, accepted for publication on $23^{\text {rd }}$ December 2019 Published online on $25^{\text {th }}$ December 2019

Aleksandra Zecevic is an associate professor at the Faculty of Economics, University of Belgrade where she obtained her PhD. She teaches Databases, Programming Languages, New Information Technology at bechalor and master studies. Her fields of expertise are: databases, programming, and e-commerce.

Jelena Radovic-Stojanovic is an assistant professor at the Academy of Criminalistic and Police Studies in Belgrade. She obtained her PhD at the Faculty of Economics, University of Belgrade. She teaches Fundamentals of Economics, Public Finance, and Information Systems in Economics. Her research areas include macroeconomics and the economic policy, economic statistics, and business informatics.

Aleksandar Cudan is an associate professor at the Academy of Criminalistic and Police Studies in Belgrade. He obtained his PhD at the Faculty of Economics in Subotica, University of Novi Sad. He teaches Economic Crime, Information System Management and Information Systems in Economics. 


\section{APPENDIX}

Table 1 The indicators of ICT implementation in enterprises (\% of the enterprises), EU-28, 2017-2018

\begin{tabular}{|c|c|c|c|c|c|c|c|c|c|c|}
\hline $\begin{array}{l}\text { countryl } \\
\text { indicator }\end{array}$ & $\begin{array}{l}\text { Enterprises use } \\
\text { DSL or another } \\
\text { fixed broadband } \\
\text { connection (2018) }\end{array}$ & $\begin{array}{l}\text { Enterprises } \\
\text { with a } \\
\text { website } \\
(2018)\end{array}$ & $\begin{array}{l}\text { Enterprises } \\
\text { using social } \\
\text { media (2017) }\end{array}$ & $\begin{array}{l}\text { Enterprises } \\
\text { using social } \\
\text { networks } \\
(2017)\end{array}$ & $\begin{array}{l}\text { Buying cloud } \\
\text { computing } \\
\text { services (2018) }\end{array}$ & $\begin{array}{l}\text { Enterprises having } \\
\text { received orders } \\
\text { via computer } \\
\text { mediated } \\
\text { networks (2018) }\end{array}$ & $\begin{array}{l}\text { Enterprises' } \\
\text { total turnover } \\
\text { from } \\
\text { e-commerce } \\
\text { (2018) }\end{array}$ & $\begin{array}{l}\text { Enterprises } \\
\text { which have } \\
\text { ERP software } \\
\text { package }\end{array}$ & $\begin{array}{l}\text { Enterprises } \\
\text { using CRM } \\
\text { (2017) }\end{array}$ & $\begin{array}{l}\text { Enterprises } \\
\text { using SCM } \\
(2017)\end{array}$ \\
\hline \multirow{21}{*}{$\begin{array}{l}\text { Austrija } \\
\text { Belgija } \\
\text { Bugarska } \\
\text { Ceska } \\
\text { Danska } \\
\text { Estonija } \\
\text { Finska } \\
\text { Francuska } \\
\text { Grcka } \\
\text { Holandija } \\
\text { Hrvatska } \\
\text { Irska } \\
\text { Italija } \\
\text { Kipar } \\
\text { Letonija } \\
\text { Litvanija } \\
\text { Luksemburg } \\
\text { Mađarska } \\
\text { Malta } \\
\text { Nemačka } \\
\text { Poljska } \\
\text { Portugalija } \\
\text { Rumunija } \\
\text { Slovačka } \\
\text { Slovenija } \\
\text { Španija } \\
\text { Svedska } \\
\text { Ujedinjeno } \\
\text { Kraljevstvo }\end{array}$} & & 88 & 53 & 51 & 23 & 18 & 14 & 40 & 43 & 16 \\
\hline & $\begin{array}{l}96 \\
84\end{array}$ & $\begin{array}{l}84 \\
51\end{array}$ & $\begin{array}{l}58 \\
34\end{array}$ & $\begin{array}{l}57 \\
34\end{array}$ & $\begin{array}{c}40 \\
8\end{array}$ & $\begin{array}{c}30 \\
8\end{array}$ & $\begin{array}{l}32 \\
5\end{array}$ & $\begin{array}{l}54 \\
23\end{array}$ & $\begin{array}{l}42 \\
18\end{array}$ & $\begin{array}{l}26 \\
17\end{array}$ \\
\hline & 97 & 83 & $\begin{array}{l}34 \\
36\end{array}$ & 34 & 26 & 25 & 29 & 28 & 18 & 12 \\
\hline & 100 & 96 & 68 & 67 & 56 & 32 & 23 & 40 & 36 & 23 \\
\hline & $\begin{array}{l}98 \\
97\end{array}$ & $\begin{array}{l}78 \\
96\end{array}$ & $\begin{array}{l}40 \\
63\end{array}$ & $\begin{array}{l}39 \\
61\end{array}$ & $\begin{array}{l}34 \\
65\end{array}$ & $\begin{array}{l}20 \\
24\end{array}$ & $\begin{array}{l}15 \\
21\end{array}$ & $\begin{array}{l}28 \\
39\end{array}$ & $\begin{array}{l}23 \\
37\end{array}$ & 15 \\
\hline & 94 & 69 & 41 & 39 & 19 & 19 & 22 & $\begin{array}{l}39 \\
38\end{array}$ & $\begin{array}{l}31 \\
27\end{array}$ & 13 \\
\hline & 84 & 65 & 50 & 49 & 13 & 12 & 4 & 37 & 18 & 10 \\
\hline & 99 & 94 & 68 & 66 & 48 & 27 & 15 & 48 & 46 & 19 \\
\hline & $\begin{array}{l}92 \\
93\end{array}$ & $\begin{array}{l}73 \\
79\end{array}$ & $\begin{array}{l}45 \\
68\end{array}$ & $\begin{array}{l}41 \\
67\end{array}$ & $\begin{array}{l}31 \\
45\end{array}$ & $\begin{array}{l}18 \\
35\end{array}$ & $\begin{array}{l}12 \\
35\end{array}$ & $\begin{array}{l}26 \\
28\end{array}$ & $\begin{array}{l}19 \\
31\end{array}$ & $\begin{array}{l}19 \\
12\end{array}$ \\
\hline & 91 & 71 & 44 & 42 & 23 & 14 & 11 & 37 & 29 & 11 \\
\hline & 94 & 71 & 67 & 65 & 27 & 14 & 4 & 35 & 42 & 17 \\
\hline & $\begin{array}{l}81 \\
96\end{array}$ & $\begin{array}{l}63 \\
78\end{array}$ & $\begin{array}{l}30 \\
50\end{array}$ & $\begin{array}{l}29 \\
47\end{array}$ & $\begin{array}{l}15 \\
23\end{array}$ & $\begin{array}{l}13 \\
22\end{array}$ & $\begin{array}{c}6 \\
13\end{array}$ & $\begin{array}{l}25 \\
47\end{array}$ & $\begin{array}{l}15 \\
32\end{array}$ & $\begin{array}{c}6 \\
28\end{array}$ \\
\hline & 97 & 83 & 54 & $\begin{array}{l}47 \\
52\end{array}$ & $\begin{array}{l}23 \\
25\end{array}$ & $\begin{array}{l}22 \\
16\end{array}$ & 15 & $\begin{array}{l}47 \\
41\end{array}$ & $\begin{array}{l}33 \\
39\end{array}$ & $\begin{array}{l}20 \\
18\end{array}$ \\
\hline & $\begin{array}{l}83 \\
94\end{array}$ & $\begin{array}{l}6 \overline{6} \\
82\end{array}$ & $\begin{array}{l}38 \\
73\end{array}$ & $\begin{array}{l}36 \\
73\end{array}$ & $\begin{array}{l}18 \\
37\end{array}$ & 15 & 23 & 14 & 13 & 9 \\
\hline & $\begin{array}{l}94 \\
93\end{array}$ & $\begin{array}{l}82 \\
87\end{array}$ & $\begin{array}{l}73 \\
45\end{array}$ & $\begin{array}{l}73 \\
40\end{array}$ & $\begin{array}{l}37 \\
22\end{array}$ & $\begin{array}{l}22 \\
22\end{array}$ & $\begin{array}{l}\dot{1} \\
14\end{array}$ & $\begin{array}{l}29 \\
38\end{array}$ & $\begin{array}{l}24 \\
46\end{array}$ & $\begin{array}{l}11 \\
30\end{array}$ \\
\hline & 87 & 67 & 27 & 26 & 11 & 14 & 15 & 26 & 23 & 21 \\
\hline & 96 & 63 & 46 & 45 & 25 & 19 & 18 & 40 & 24 & 17 \\
\hline & $\begin{array}{l}82 \\
89\end{array}$ & $\begin{array}{l}44 \\
76\end{array}$ & $\begin{array}{l}35 \\
39\end{array}$ & $\begin{array}{l}34 \\
35\end{array}$ & $\begin{array}{l}10 \\
21\end{array}$ & $\begin{array}{l}9 \\
16\end{array}$ & $\begin{array}{c}9 \\
21\end{array}$ & $\begin{array}{l}17 \\
31\end{array}$ & $\begin{array}{l}13 \\
22\end{array}$ & $\begin{array}{l}7 \\
15\end{array}$ \\
\hline & 99 & 84 & 47 & 45 & 26 & 25 & 17 & 30 & 25 & 15 \\
\hline & $\begin{array}{l}91 \\
93\end{array}$ & $\begin{array}{l}76 \\
92\end{array}$ & $\begin{array}{l}51 \\
65\end{array}$ & $\begin{array}{l}49 \\
63\end{array}$ & $\begin{array}{l}22 \\
57\end{array}$ & $\begin{array}{l}20 \\
32\end{array}$ & $\begin{array}{l}17 \\
24\end{array}$ & $\begin{array}{l}46 \\
31\end{array}$ & $\begin{array}{l}34 \\
34\end{array}$ & $\begin{array}{l}17 \\
13\end{array}$ \\
\hline & 93 & 82 & 63 & 60 & 42 & 22 & 19 & 19 & 31 & 12 \\
\hline
\end{tabular}

Source: Authors

Table 2 The ranking of the enterprises by the value of ICT usage indicators in the enterprises, EU-28, 2017-2018

\begin{tabular}{|c|c|c|c|c|c|c|c|c|c|c|}
\hline & $\begin{array}{l}\text { Enterprises use } \\
\text { DSL or another } \\
\text { fixed broadband } \\
\text { connection (2018) }\end{array}$ & $\begin{array}{l}\text { Enterprises } \\
\text { with a } \\
\text { website } \\
\text { (2018) }\end{array}$ & $\begin{array}{l}\text { Enterprises } \\
\text { using social } \\
\text { media (2017) }\end{array}$ & $\begin{array}{l}\text { Enterprises } \\
\text { using social } \\
\text { networks } \\
(2017)\end{array}$ & $\begin{array}{l}\text { Buying cloud } \\
\text { computing } \\
\text { services (2018) }\end{array}$ & $\begin{array}{l}\text { Enterprises having } \\
\text { received orders } \\
\text { via computer } \\
\text { mediated } \\
\text { networks (2018) }\end{array}$ & $\begin{array}{l}\text { Enterprises' } \\
\text { total turnover } \\
\text { from } \\
\text { e-commerce } \\
(2018)\end{array}$ & $\begin{array}{l}\text { Enterprises } \\
\text { which have } \\
\text { ERP software } \\
\text { package }\end{array}$ & $\begin{array}{l}\text { Enterprises } \\
\text { using CRM } \\
\text { (2017) }\end{array}$ & $\begin{array}{l}\text { Enterprises } \\
\text { using SCM } \\
\text { (2017) }\end{array}$ \\
\hline Austrija & 21 & 5 & 11 & 11 & 18 & 18 & 19 & 7 & 3 & 14 \\
\hline Belgija & 8 & 7 & 9 & 9 & 7 & 4 & 2 & 1 & 4 & 3 \\
\hline Bugarska & 24 & 27 & 26 & 26 & 28 & 28 & 25 & 25 & 23 & 10 \\
\hline Česka & 5 & 9 & 24 & 24 & 12 & 6 & 3 & 19 & 24 & 20 \\
\hline Danska & 1 & 1 & 2 & 2 & 3 & 2 & 5 & 6 & 8 & 4 \\
\hline Estonija & 4 & 14 & 21 & 21 & 9 & 13 & 14 & 20 & 19 & 15 \\
\hline Finska & 7 & 2 & 7 & 7 & 1 & 8 & 9 & 9 & 7 & 5 \\
\hline Francuska & 11 & 21 & 20 & 20 & 22 & 15 & 7 & 11 & 15 & 18 \\
\hline Grčka & 25 & 24 & 13 & 13 & 25 & 26 & 26 & 12 & 25 & 25 \\
\hline Holandija & 2 & 3 & 4 & 4 & 4 & 5 & 16 & 2 & 2 & 8 \\
\hline Hrvatska & 18 & 18 & 18 & 18 & 10 & 17 & 21 & 22 & 22 & 7 \\
\hline Irska & 15 & 13 & 3 & 3 & 5 & 1 & 1 & 21 & 12 & 21 \\
\hline Italija & 20 & 19 & 19 & 19 & 16 & 22 & 22 & 13 & 14 & 23 \\
\hline Kipar & 12 & 20 & 5 & 5 & 11 & 23 & 27 & 14 & 5 & 12 \\
\hline Letonija & 28 & 25 & 27 & 27 & 24 & 25 & 24 & 24 & 26 & 28 \\
\hline Litvanija & 9 & 15 & 14 & 14 & 17 & 10 & 20 & 3 & 11 & 2 \\
\hline Luksemburg & 6 & 10 & 10 & 10 & 14 & 19 & 15 & 5 & 6 & 9 \\
\hline Mađarska & 26 & 23 & 23 & 23 & 23 & 21 & 6 & 28 & 27 & 26 \\
\hline Malta & 13 & 11 & 1 & 1 & 8 & 11 & 28 & 18 & 17 & 24 \\
\hline Nemačka & 14 & 6 & 17 & 17 & 19 & 9 & 18 & 10 & 1 & 1 \\
\hline Poljska & 23 & 22 & 28 & 28 & 26 & 24 & 17 & 23 & 20 & 6 \\
\hline Portugalija & 10 & 26 & 16 & 16 & 15 & 16 & 11 & 8 & 18 & 13 \\
\hline Rumunija & 27 & 28 & 25 & 25 & 27 & 27 & 23 & 27 & 28 & 27 \\
\hline Slovačka & 22 & 17 & 22 & 22 & 21 & 20 & 8 & 15 & 21 & 17 \\
\hline Șlovenija & 3 & 8 & 15 & 15 & 13 & 7 & 13 & 17 & 16 & 16 \\
\hline Španija & 19 & 16 & 12 & 12 & 20 & 14 & 12 & 4 & 9 & 11 \\
\hline Švedska & 16 & 4 & 6 & 6 & 2 & 3 & 4 & 16 & 10 & 19 \\
\hline $\begin{array}{l}\text { Ueadinjeno } \\
\text { Kraljevstvo }\end{array}$ & 17 & 12 & 8 & 8 & 6 & 12 & 10 & 26 & 13 & 22 \\
\hline
\end{tabular}

Source: Authors 


\title{
PRIMENA INFORMACIONO-KOMUNIKACIONIH TEHNOLOGIJA U PREDUZEĆIMA U ZEMLJAMA EVROPSKE UNIJE
}

\author{
Aleksandra Zečević ${ }^{* 1}$, Jelena Radović Stojanovići Aleksandar Čudan² \\ ${ }^{1}$ Ekonomski fakultet Univerziteta u Beogradu \\ ${ }^{2}$ Kriminalističko-policijski univerzitet, Departman kriminalistike, Beograd
}

\begin{abstract}
U radu se analizira primena informaciono-komunikacionih tehnologija (IKT) u preduzećima u zemljama članicama Evropske unije (EU). Ciljevi analize bili su da se ispita dostignuti nivo u primeni IKT u preduzećima i da se istraže razlike u korišćenju IKT koje postoje među zemljama članicama EU. U analizi su korišćeni podaci EUROSTAT-a o primeni IKT u preduzećima Evropske unije (EU-28) za 2017. i 2018. Analizirani su sledeći indikatori primene IKT u preduzećima: širokopojasna internet konekcija, brzina internet konekcije, prisustvo na internetu (posedovanje web sajta), korišćenje društvenih medija, korišćenje cloud računarstva, indikatori e-trgovine (udeo preduzeća koja prodaju svoje proizvode preko interneta i učešće e-trgovine $u$ ukupnom prometu), i indikatori integrisanosti e-poslovanja (udeo preduzeća koja koriste integralni poslovni software, software za upravljanje odnosima sa klijentima i softver za upravljanje lancem snabdevanja). Izvršena je komparativna analiza zemalja EU po vrednosti ovih indikatora, sa ciljem da se utvrdi koji faktori utiču na razlike u vrednosti indikatora među zemljama. Analiza je pokazala da su regionalni položaj, geografske karakteristike, veličina zemlje i dostignut nivo ekonomskog razvoja faktori koji utiču na ove razlike.
\end{abstract}

Ključne reči: informaciono-komunikacione tehnologije, e-trgovina, indikatori integrisanosti e-poslovanja, preduzeća, Evropska unija

\section{JEL Classification: O330, L86}

\section{UVOD}

Uprkos velikoj pažnji koja se poklanja primeni i razvoju informaciono-komunikacionih tehnologija (IKT) u zemljama EU, kao i značaju koji im se pridaje

* Korespondencija: A. Zečević, Ekonomski fakultet Univerziteta u Beogradu, Kamenička 6, 11000 Beograd, Republika Srbija; e-mail: azecevic@ekof.bg.ac.rs u javnosti, medijima i nauci, još uvek ima tema, pa i čitavih oblasti u vezi sa primenom IKT koje su nedovoljno obrađene. Ovo naročito važi kada je $u$ pitanju njiihova primena u preduzećima (druga velika oblast analize je primena IKT od strane pojedinica i domaćinstava). Ovaj rad se bavi jednom od takvih, za sada nedovoljno istraženih tema i analizira dostignut nivo u primeni IKT u preduzećima u zemljama EU. 
Iako postoji jedno opšte mišljenje da su zemlje EU zbog svoje ekonomske razvijenosti daleko stigle u primeni IKT, još uvek postoje značajne razlike među njima $u$ tom pogledu. Ciljevi ovog rada bili su: da se analizira dostignut nivo $u$ primeni IKT $u$ preduzećima u zemljama EU, da se istraže razlike u primeni IKT i da se identifikuje koji faktori utiču na primenu IKT u preduzećima. Evropske institucije, pre svega, Evropska komisija i Eurostat, bave se ovim pitanjima, ali su u svojim analizama uglavnom fokusirane na zemlje članice pojedinačno. Predmet ovog rada je bio pre uočavanje pravilnosti, sinteza zaključaka u pogledu faktora koji utiču na primenu IKT $u$ preduzećima generalno, nego što je to bila analiza samo jedne pojedinačne zemlje ili grupe zemalja unutar EU.

Kako se zemlje članice EU među sobom značajno razlikuju po svojim karakteristikama (počevši od broja stanovnika, površine, geografskog položaja, istorijskog i kulturnog nasleđa, preko strukture privrede, pa do dostignutog nivoa društvenog i ekonomskog razvoja, nivoa tehničko-tehnološke razvijenosti, i tako dalje), $\mathrm{u}$ istraživanju se pošlo od hipoteze da razlike koje postoje među zemljama članicama, koje se odražavaju na sve aspekte ekonomskog i društvenog života, imaju uticaja i na dostignut nivo u usvajanju i primeni informacionokomunikacionih tehnologija. Postavilo se pitanje: koje su to razlike, odnosno, koje su to karakteristike zemalja koje utiču na primenu IKT, konkretno, na primenu IKT u preduzećima? Da bi se odgovorilo na ovo pitanje, posmatrani su statistički indikatori primene IKT u preduzećima koje prikuplja i objavljuje EUROSTAT i izvršena je komparativna analiza među zemljama po vrednosti ovih indikatora.

Na početku rada, dat je pregled literature koja se bavi primenom IKT u zemljama EU. Zatim je, u osnovnim crtama, predstavljena metodologija Eurostat-a koja se koristi u prikupljanju podataka i izračunavanju indikatora primene IKT u preduzećima. U glavnom delu rada izvršena je analiza izabranih indikatora i komparativna analiza među zemljama, sa ciljem da se identifikuju faktori koji utiču na razlike $\mathrm{u}$ vrednosti indikatora među zemljama. U Zaključku su rezimirani glavni rezultati analize. Na kraju rada, $\mathrm{u}$ Prilogu, date su tabele, $\mathrm{u}$ kojima je prikazan rang zemalja članica EU po vrednostima indikatora.

\section{PREGLED LITERATURE}

O tome da su istraživanja koja se bave ekonomskim aspektima primene IKT skoncentrisana na relativno mali broj tema, ukazali su N. Roztocki i H. R. Weistroffer (2015). Do danas se nije mnogo toga promenilo, pa tako $\mathrm{u}$ istraživanjima preovladava nekoliko tema: uticaj IKT na način poslovanja preduzeća i podizanje efikasnosti i konkurentnosti preduzeća (Real, Leal \& Roldán, 2006), uticaj IKT na privredni rast i razvoj (Stankic, Jovanovic Gavrilovic \& Soldic Aleksic, 2018), na ekonomiju i društvo u celini (Roztocki, Soja \& Weistroffer, 2019). Ako se u primeni IKT u organizacijama, analizira usvajanje, implementacija, primena i efekti (Bouwman, van der Hooff, van der Wijngaert \& van Dijk, 2005), moglo bi se reći da se, naučni radovi bave, uglavnom, efektima IKT na poslovanje i rad preduzeća, dok su implementacija IKT i njihova primena u preduzećima nedovoljno obrađeni, o čemu svedoči mali broj radova. U poslednje vreme aktuelno je usvajanje naprednih IKT tehnologija kao što su cloud računarstvo i big data analiza, na koje se poslednjih nekoliko godina naročito usmerila pažnja istraživača (o najvažnijim karakteristikama i koncepcijama big data videti u Chroneos-Krasavac, Soldic-Aleksic \& Petkovic, 2016).

Što se tiče literature koja se bavi primenom IKT u zemljama EU, najvažniji izvor podataka i analiza je Evropska komisija. Svake godine Evropska komisija izrađuje Izveštaj o progresu u digitalizaciji (European Digital Progress Report - EDPR), koji sadrži digitalni profil svake zemlje (Country Profile). U ovom dokumentu analizira se progres zemalja članica EU u digitalizaciji. U evaluaciji se koristi vrednost Digital Economy and Society Index (DESI), u kombinaciji sa kvalitativnom analizom (European commision, 2017). DESI je kompozitni indeks koji objavljuje Evropska komisija, kojim se kvantitativno izražava napredak u digitalizaciji (European commission, 2019). Kvalitativna analiza obuhvata analizu specifičnih uslova i politika u zemljama. U oceni dostignutog 
nivoa $\mathrm{u}$ primeni IKT $\mathrm{u}$ zemljama, izbegavaju se vrednosni sudovi (na primer, razvijena/nerazvijena), već se zemlje dele na srednje, visoko i nisko uspešne zemlje. Tako, na primer, zemlje koje su po vrednosti DESI indeksa na nivou proseka su srednje uspešne zemlje (medium performing countries), one koje su iznad proseka su visoko uspešne (high performing), a ispod proseka - manje uspešne zemlje (low performing countries). Jedan veliki deo Izveštaja o progresu u digitalizaciji, pod nazivom Digitalizacija preduzeća (Digitisation of enterprises) odnosi se na primenu IKT u preduzećima.

Izveštaj o progresu u digitalizaciji je veoma detaljan i sadrži mnogo podataka. Evropska komisija objavljuje i veliki broj analiza i studija koji se bave primenom IKT u evropskim ekonomijama. S druge strane, naučnih radova u ovoj oblasti nema dovoljno. Posmatrajući stručnost izveštaja Evropske komisije i obilje podataka koji se objavljuju, moglo bi se pomisliti da je dovoljno da se samo Evropska komisija bavi podacima, statistikom i analizama. Međutim, osim tog stručnog ugla posmatranja, nedostaje u literaturi istraživačka inicijativa koja nije vezana isključivo za evropske institucije. Ima još dosta prostora za istraživanja i svaki novi aspekt analize i drugačiji ugao posmatranja bi mogao biti od koristi i dati nove uvide.

U nekoliko naučnih radova koji se bave primenom IKT u evropskim zemljama, učinjeni su napori da se zemlje rangiraju na osnovu dostignutog nivoa primene i da se identifikuju faktori od uticaja na proces prihvatanja IKT. J. Becker, A. Becker, P. Sulikowski i T. Zdziebko, (2018) rangiraju zemlje Centralne Evrope, članice EU (Austrija, Republika Češka, Nemačka, Mađarska, Slovačka i Slovenija) prema primeni IKT u preduzećima, koristeći Analytic Network Process (ANP). Istraživanje je pokazalo da su u ovoj grupi zemalja Slovenija i Austrija lideri u pogledu primene IKT u preduzećima za 2017. A. Zečević i J. Radović Stojanović (2018) analiziraju primenu IKT u Sloveniji, Hrvatskoj, Republici Srbiji, Bosni i Hercegovini, Makedoniji i Crnoj Gori. Kao faktori od uticaja na primenu IKT u ovim zemljama identifikovani su investicije, i razvijenost informaciono-komunikacione infrastrukture. Zaključak istraživanja bio je da zemlje članice EU - Slovenija i Hrvatska prednjače u pogledu primene IKT $\mathrm{u}$ svojim preduzećima, naročito $\mathrm{u}$ prihvatanju naprednih tehnologija, cloud računarstva i e-trgovine. R. Stankić i D. Stojković (2017) razmatraju primenu IKT u preduzećima u Republici Srbiji, uz poređenje sa evropskim prosekom.

Ocenom dostignutog nivoa $u$ primeni IKT $i$ rangiranjem država bave se i Ujedinjene nacije (UN), koje rangiraju zemlje na osnovu vrednosti IDI indeksa (ICT Development Index - IDI), kompozitnog indeksa koji je baziran na 11 IKT indikatora. Na osnovu IDI indeksa za 2017, najbolje rangirane članice EU su Danska, Velika Britanija i Holandija (United Nations, 2018). J. Soldić Aleksić i R. Stankić (2015) predstavili su Networked Readiness Index (NRI), kompozitni indeks koji izračunava i objavljuje Svetski ekonomski forum (World Economic Forum). Na osnovu Globalnog izveštaja o informacionim tehnologijama (Global Information Technology Report) koji ova organizacija objavljuje, šest evropskih zemalja (Finska, Švedska, Norveška, Holandija, Švajcarska i Ujedinjeno Kraljevstvo) nalaze se među 10 najbolje rangiranih zemalja po vrednosti NRI indeksa (World Economic Forum, 2016). Struktura NRI je kompleksna, jer se sastoji od 54 indikatora primene IKT u ekonomiji i društvu. Što se tiče podele evropskih zemalja po uspešnosti u primeni IKT na osnovu ovog indeksa, ona je regionalna, pri čemu se ocenjuje da su zemlje Južne, Centralne i Istočne Evrope u zaostatku za zemljama Severne i Srednje Evrope.

\section{IZVORI PODATAKA I METODOLOGIJA}

Podaci o primeni IKT u preduzećima koje objavljuje Eurostat rezultat su statističkog istraživanja pod nazivom "Usage of information-communication technologies (ICT) in Enterprises". Istraživanje se sprovodi jednom godišnje od 2002. u svim zemljama članicama EU. Istraživanjem se prikupljaju podaci o primeni IKT u preduzećima, korišćenju interneta, elektronskom poslovanju preduzeća i drugim relevantnim aspektima primene IKT u preduzećima. Rezultati istraživanja se objavljuju u okviru statističke oblasti Digitalna ekonomija i društvo (Digital economy and society), na Internet sajtu Eurostat-a (Statistička 
oblast Digitalna ekonomija i društvo u Bazi podataka Eurostat). Rezultati se objavljuju i u publikacijama Eurostat-a kao i u bazi podataka Eurostat-a.

Metodološku osnovu istraživanja čine uputstva Eurostat-a za sprovođenje istraživanja koja sadrži Metodološki priručnik za statistiku informacionog društva (Eurostat, 2018). U Metodološkom priručniku definisane su jedinice posmatranja, cilj istraživanja, vremenski period, ciljna populacija, date su definicije varijabli koje se obuhvataju, nazivi indikatora koji se izračunavaju i agregata koji se dobijaju, sistem uzorkovanja, koncepti, nomenklature i svi drugi elementi statističkog istraživanja. Zajednička metodologija doprinela je da podaci koji se dobijaju na osnovu istraživanja u svim zemljama EU budu uporedivi. Istraživanje na osnovu ove metodologije sprovodi se i u drugim evropskim državama koje nisu članice EU.

Metodologija istraživanja propisuje da su jedinice posmatranja, to jest, izveštajne jedinice $u$ istraživanju preduzeća sa 10 i više zaposlenih. Preduzeća su, u zavisnosti od broja zaposlenih, podeljena na mala (10-49), srednja (50-249) i velika preduzeća (više od 250 zaposlenih). Istraživanje se sprovodi na osnovu upitnika koji sadrži pitanja koja su grupisana po modulima. Ovi moduli su: Primena računara, IKT stručnjaci i veštine, Pristup i korišćenje interneta, Korišćenje usluga cloud računarstva, E-trgovina, Elektronsko fakturisanje, Big data analiza. U najnovijoj verziji metodologije, istraživanje je prošireno sa sledećim modulima: Korišćenje 3-D štampača i Korišćenje robotike. Upitnik se popunjava $u$ preduzećima telefonski, ili se šalje putem elektronske pošte. Podaci se dostavljaju nacionalnim statističkim zavodima koji ove podatke obrađuju, skladište $\mathrm{u}$ bazama podataka i objavljuju u odgovarajućim publikacijama.

U radu su analizirani: širokopojasna internet konekcija u preduzećima, brzina internet konekcije, prisustvo na internetu (posedovanje web sajta), korišćenje društvenih medija, primena cloud računarstva, indikatori e-trgovine (udeo preduzeća koja učestvuju u e-trgovini i učešće e-trgovine u ukupnom prometu) i indikatori integrisanosti e-poslovanja: udeo preduzeća koja koriste integralni poslovni software (Enterprise Recource Planning - ERP software), software za upravljanje odnosima sa klijentima (customer relationship management - CRM software) i software za upravljanje lancem snabdevanja (supply chain management - SCM software). EUROSTAT prikuplja veliki broj podataka i izračunava i brojne druge indikatore primene IKT u preduzećima, a indikatori koji su posmatrani u ovom radu izabrani su jer su to indikatori koje i sam EUROSTAT izdvaja kao reprezentativne i najčešće koristi u svojim analizama. Polazeći od indikatora EUROSTAT-a, u radu je izvršena komparativna analiza vrednosti izabranih indikatora po zemljama, s jedne, i karakteristika zemalja, s druge strane, kako bi se uočile pravilnosti, grupisale zemlje koje imaju vrednosti indikatora na približno istom nivou i identifikovali faktori koji utiču na primenu IKT u preduzećima.

\section{INDIKATORI PRIMENE IKT U PREDUZEĆIMA EVROPSKE UNIJE - EMPIRIJSKI PODACI I ANALIZA}

$\mathrm{U}$ radu su korišćeni podaci o primeni IKT $\mathrm{u}$ preduzećima u zemljama članicama EU. Podaci su preuzeti iz Baze podataka Eurostat-a. U analizi su korišćeni podaci za 2018, a tamo gde podaci za 2018. nisu još uvek objavljeni, korišćeni su poslednji raspoloživi podaci, odnosno, podaci za 2017.

U 2018, 92\% preduzeća u EU koristilo je fiksnu širokopojasnu internet konekciju. Ovaj udeo preduzeća od preko 90\% dostignut je 2012, od kada se nije mnogo promenio i od godine do godine kreće se između 92\% i 93\% preduzeća (Slika 1). Udeo preduzeća koja koriste fiksnu širokopojasnu internet konekciju je pokazatelj razvijenosti informatičke infrastrukture i po zemljama kreće se u rasponu od $81 \%$ preduzeća u Letoniji do $100 \%$ u Danskoj. Visok udeo preduzeća imaju Belgija (96\%), Holandija (99\%), Luksemburg (97\%) dok su velike evropske ekonomije Nemačka (93\%), Francuska (94\%), Italija (91\%) i Španija (91\%) na nivou proseka. Zemlje u kojima je učešće preduzeća koja imaju fiksnu širokopojasnu konekciju ispod 90\% su Rumunija (82\%), Mađarska (83\%), 
Bugarska (84\%), Poljska (87\%), Slovačka (89\%), Češka (89\%) i Grčka (84\%). Sa izuzetkom Grčke, to su zemlje Centralne i Istočne Evrope. Grčka je primorska zemlja, sa dugačkom, razuđenom obalom i velikim brojem ostrva i poluostrva, što diktira određene specifičnosti u pogledu razvoja informatičke infrastrukture. Kao što će se u radu videti, ima i drugih pokazatelja koji su zajednički za pojedine primorske i ostrvske zemlje.

Osnovni vid prisustva na internetu za preduzeća je posedovanje web sajta. Preduzeća svoj web sajt koriste za pružanje opisa robe ili usluga, isticanje cenovnika, upoznavanje kupaca sa proizvodima, sadrže linkove prema društvenim mrežama, on-line naručivanje i praćenje porudžbina. U 2018, 77\% preduzeća u zemljama EU je posedovalo svoj web sajt, a od 2012. godine povećao se za 7\% (Slika 1). Zemlje u kojima je udeo preduzeća koja poseduju web sajt veći od $90 \%$ su Švedska (92\%), Finska (96\%), Danska (96\%), kao i zemlje Beneluksa, Belgija (84\%), Holandija (94\%) i Luksemburg (83\%). Visok procenat preduzeća koja poseduju web sajt imaju i velike razvijene evropske ekonomije kao što su Nemačka (87\%) i Velika Britanija (82\%) ali i Češka (83\%), dok Francuska (69\%), Italija (71\%) i Španija (76\%) imaju udeo preduzeća koja poseduju web sajt ispod evropskog proseka. Najniži udeo preduzeća koja poseduju web sajt je u Letoniji (63\%), Rumuniji (44\%), Bugarskoj (51\%) i Mađarskoj (66\%).
Drugi važan pokazatelj razvijenosti infrastrukture je brzina internet konekcije. U 2018, 20\% preduzeća EU-28 je imalo brzinu internet konekcije u rasponu od 2 do $10 \mathrm{Mb} / \mathrm{s}, 24 \%$ preduzeća u rasponu od 10 do $30 \mathrm{Mb} / \mathrm{s}$, 25\% preduzeća u rasponu od 30 do 100 $\mathrm{Mb} / \mathrm{s}$, a brzinu konekcije veću od $100 \mathrm{Mb} / \mathrm{s}$ imalo je 18\% preduzeća (Slika 2). Udeo preduzeća koja koriste sporiju internet konekciju poslednjih pet godina opada, dok je udeo preduzeća koja koriste veću brzinu konekcije u porastu. Ovaj trend je prisutan $u$ većini zemalja, bez obzira na strukturu preduzeća u pogledu brzine konekcije.

Jedan od najvažnijih aspekata korišćenja interneta u preduzećima je korišćenje društvenih medija. Vidovi društvenih medija su: društvene mreže, multimedijalni sajtovi za razmenu sadržaja (Youtube, Flickr, Picassa), blog preduzeća (Twitter) i wiki izvori podataka. U pojedinim evropskim zemljama društvene medije u 2017. koristilo je više od $50 \%$ preduzeća (Finska 63\%, Švedska 65\%, Holandija 68\%, Belgija 58\%, Luksemburg 54\%), dok je u drugim udeo ovih preduzeća bio oko, ili čak, ispod 30\% (Bugarska 34\%, Rumunija 35\%, Mađarska 38\%, Poljska 27\%, Češka 36\%, Slovačka 39\%).

Kako i koliko preduzeća koriste društvene medije najbolje se vidi po korišćenju društvenih mreža. Ako je zemlja manja, udaljenija od velikih evropskih

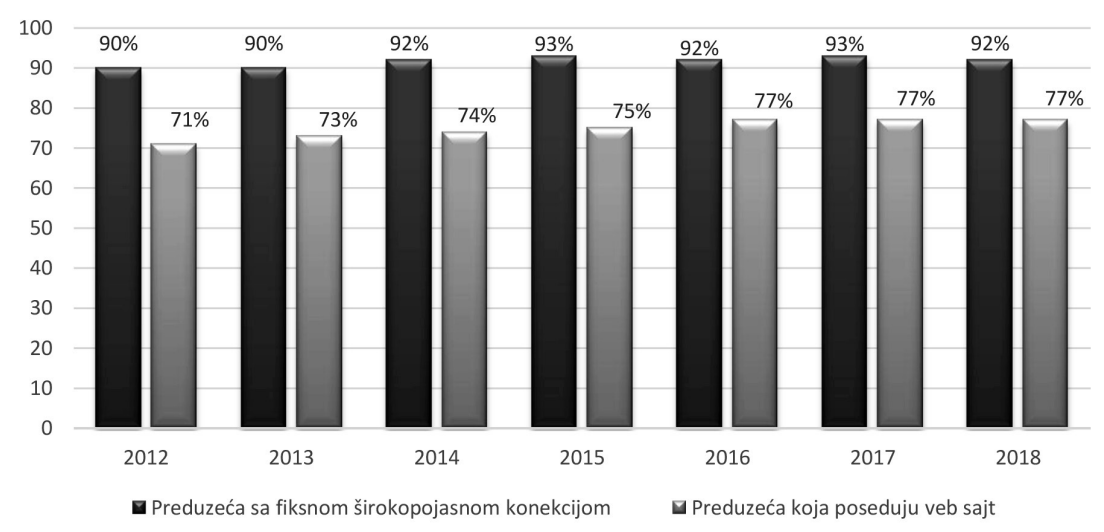

Slika 1 Preduzeća koja koriste širokopojasnu internet konekciju i preduzeća koja poseduju web sajt, EU-28, 20122018 (\% preduzeća) 
tržišta, što je teže da se dopre do potrošača na ovim tržištima i da se komunicira sa njima, to je veći procenat preduzeća koja koriste društvene mreže u svom poslovanju. Tako, najveći procenat preduzeća koja koriste društvene mreže u 2017. imaju male ostrvske zemlje Malta (73\%), Irska (67\%), Kipar (65\%), kao i Danska (67\%), Holandija (66\%), Švedska (63\%), ali i Velika Britanija, u kojoj je udeo preduzeća koja koriste društvene mreže $60 \%$. Sve ove zemlje imaju učešće preduzeća koja koriste društvene mreže koje je veće od prosečnih $45 \%$ za EU u celini. U isto vreme, preduzeća u velikim evropskim ekonomijama, zemljama Centralne Evrope, ne oslanjaju se toliko na društvene mreže u svom poslovanju, pa je udeo preduzeća koja koriste društvene mreže u ovim zemljama ispod EU-28 proseka, i iznosi 39\% u Francuskoj, 40\% u Nemačkoj, 42\% u Italiji i nešto malo više od evropskog proseka - 49\% u Španiji. Preduzeća u ovim ekonomijama imaju i druge načine da dopru do potrošača i zajedničkog evropskog tržišta, štaviše, one čine to tržište (ili bar najveći njegov deo).

Najniži procenat preduzeća koja koriste društvene mreže u svom poslovanju beleže Mađarska (36\%), Slovačka (35\%), Bugarska (34\%), Češka (34\%), Rumunija (34\%), Letonija (29\%) i Poljska (26\%). To su zemlje Centralne i Istočne Evrope, nekadašnje zemlje u tranziciji. Da će se društveno-ekonomske karakteristike ovih zemalja i dostignutnivo ekonomske razvijenost i poslovne kulture odraziti na prihvatanje i primenu IKT, nagovestili su N. Roztocki i H. R. Weistroffer (2008). Od informatičke infrastrukture, preko korišćenja interneta i posedovanja web sajta, do komunikacije sa potrošačima putem društvenih mreža, ove zemlje još uvek zaostaju za razvijenim evropskim ekonomijama. Karakteristike primene IKT u ovim zemljama su: nedostatak dugoročnog strategijskog okvira primene IKT, nizak nivo upotrebe IKT, potreba za stranom podrškom u usvajanju IKT, uticaj stranih investicija u IKT, nedovoljna orjentacija na potrošače, neadekvatno planiranje, ograničeni resursi, problemi u obrazovanju, i prihvatanju IKT od strane zaposlenih (Soja \& Cunha, 2015).

Pod uslugama cloud računarstva podrazumevaju se različite IKT usluge kojima se pristupa preko interneta: elektronska pošta, skladištenje fajlova, office software-i (Word, Excel), hosting baze podataka preduzeća, finansijske ili računovodstvene softwareske aplikacije, upotrebu software-a za upravljanje odnosima sa klijentima (Costumer Relationship Management - CRM software), povećanje računarskih kapaciteta za pokretanje software-a preduzeća (Slika 3). Na nivou EU-28, 2018. godine usluge cloud računarstva koristilo je $26 \%$ preduzeća. U korišćenju ovih usluga prednjačile su Norveška (51\%), Švedska (57\%), Finska (65\%), dok su Bugarska (8\%), Rumunija $(10 \%)$, i Poljska (11\%) imale najmanji udeo preduzeća koja koriste usluge cloud računarstvo. Nešto bliže evropskom proseku su Slovačka (21\%) i Mađarska

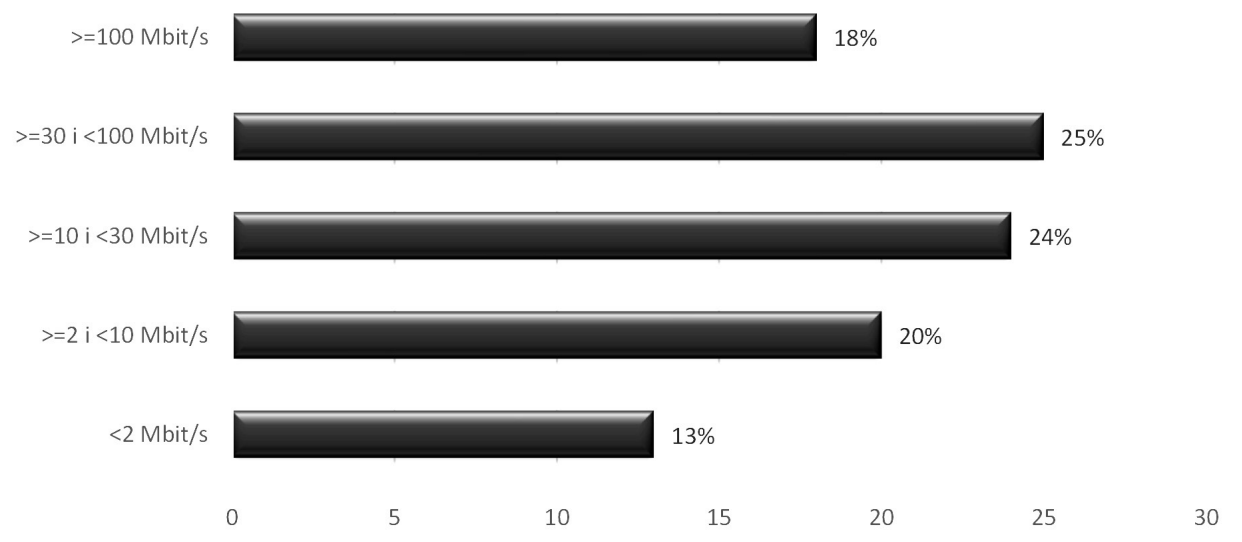

Slika 2 Brzina internet konekcije u preduzećima EU-28, 2018. 
(18\%). Velike evropske ekonomije Francuska (19\%), Nemačka (22\%), Španija (22\%) i Italija (23\%) su ispod evropskog proseka, dok male ekonomije i ostrvske zemlje kao što su Irska (45\% preduzeća), Malta (37\% preduzeća) i Hrvatska (31\%) korišćenjem cloud usluga nastoje da unaprede svoje informatičke kapacitete.

Kao i u korišćenju društvenih mreža, na primeru cloud računarstva, pokazuje se da veličina zemlje ne mora biti presudna $u$ pogledu usvajanja novih tehnologija i napretka u primeni IKT (Slika 4). I male evropske zemlje postižu značajne rezultate $u$ primeni naprednih IKT (Zečević \& Radović-Stojanović, 2017).

Indikatore elektronske trgovine Eurostat prikuplja od 2010. Dostignut nivo u razvoju elektronske trgovine $\mathrm{u}$ zemljama biće analiziran na osnovu udela preduzeća koja prodaju svoje proizvode preko interneta i udela prometa ostvarenog na ovaj način $u$ ukupnom prometu preduzeća. Prodaja preko interneta podrazumeva primanje porudžbina metodama posebno dizajniranim za primanje porudžbina kao što su elektronska razmena podataka (Electronic Data Interchange - EDI), web sajt ili posebne aplikacije (narudžbine primljene putem e-mail-a se ne uključuju) (Eurostat, 2018). Indikator prodaje preko interneta u Bazi podataka Eurostat-a je udeo preduzeća koja primaju porudžbine putem mreže (Slika 5).
U 2018. godini 20\% preduzeća u zemljama EU-28 je prodavalo svoje proizvode preko interneta. Udeo online prodaje u ukupnom prometu preduzeća je bio 17\%. Elektronska trgovina doživela je ekspanziju poslednjih godina gotovo u svim zemljama EU, a najveći udeo preduzeća koja prodaju elektronskim putem imaju skandinavske zemlje Danska (32\%), Norveška (29\%), Švedska (32\%), kao i zemlje Beneluksa Belgija (30\%) i Holandija (27\%), mada ne i Luksemburg (samo 16\%). Razvijenu elektronsku trgovinu imaju i ostrvske zemlje Island (29\%), Irska (35\%) i Malta (22\%). Ispod evropskog proseka su Bugarska (8\%), Letonija (13\%), Rumunija (9\%), Poljska (14\%), Slovačka (16\%), Mađarska (15\%) i Grčka (12\%). Velike evropske ekonomije se uglavnom kreću oko proseka za EU28 sa izuzetkom Italije (svega $14 \%$ ), pa je tako udeo preduzeća koja prodaju preko mreža u Nemačkoj 22\%, u Francuskoj 19\% a u Španiji 20\%.

U nekim slučajevima, značajan udeo elektronski ostvarenog prometa (online prodaje) imaju preduzeća u zemljama koje već imaju veliko učešće preduzeća koja prodaju preko interneta, kao na primer $\mathrm{u}$ Švedskoj (24\%), Danskoj (23\%) i Finskoj (21\%), ali se dešava i da zemlje koje imaju manji procenat preduzeća koja prodaju preko interneta ostvaruju veliko učešće tako ostvarenog prometa u ukupnom prometu. Tako, na primer, Slovačka, u kojoj samo $16 \%$ preduzeća prodaje elektronskim putem, ima

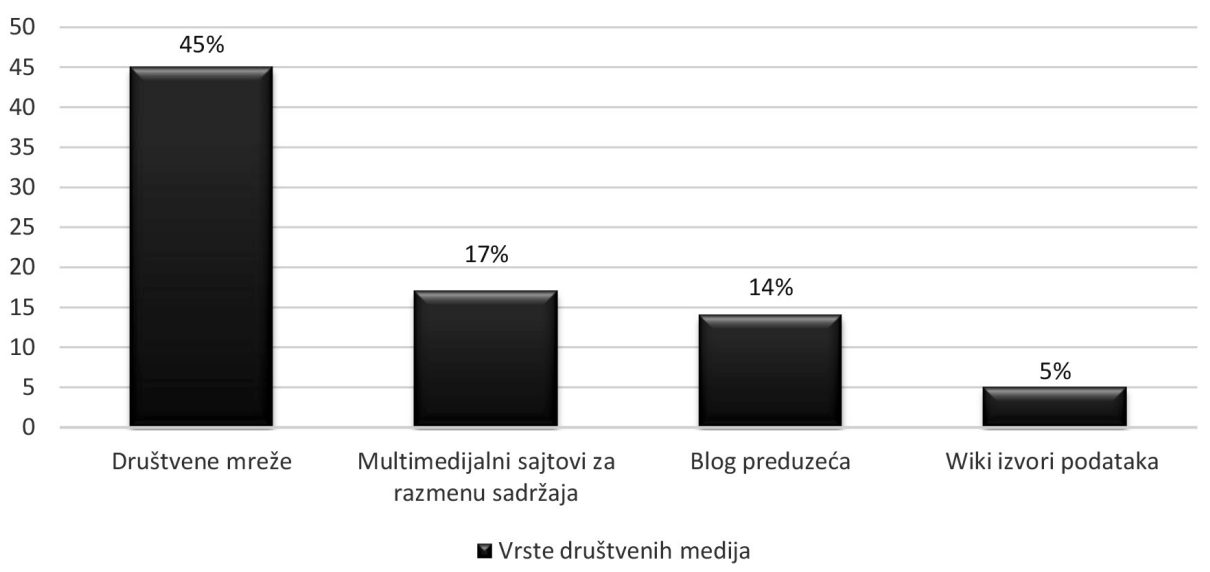

Slika 3 Korišćenje društvenih medija u zemljama EU-28, 2017. (\% preduzeća). 


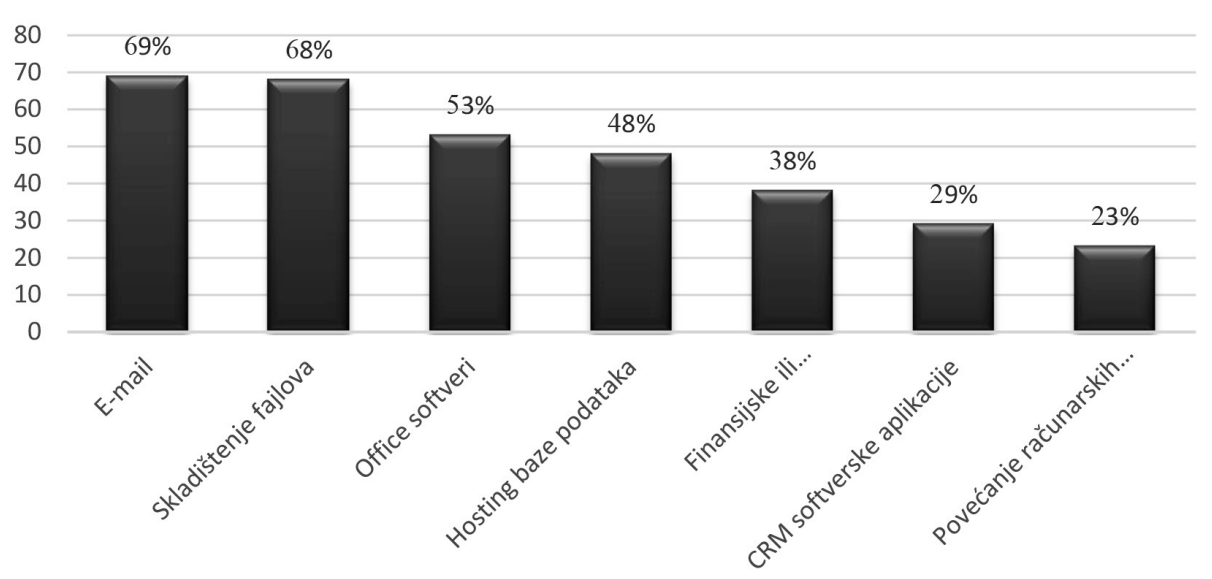

Slika 4 Korišćenje usluga cloud računarstva u zemljama EU-28, 2017. (\% preduzeća)

Izvor: Autori

udeo elektronski ostvarenog prometa od $21 \%$. S druge strane, nizak udeo elektronski ostvarenog prometa imaju Holandija (15\%) i Luksemburg (15\%), kao i pojedine velike evropske ekonomije, za koje bi se očekivalo sasvim suprotno, jer već imaju značajan procenat preduzeća koja prodaju preko interneta. Na primer, udeo elektronski ostvarenog prometa u Nemačkoj je svega $14 \%$ a u Italiji $11 \%$. Najniži udeo elektronski ostvarenog prometa imaju Bugarska (5\%), Letonija (6\%), Rumunija (9\%) i Poljska (15\%).
Integrisanost e-poslovanja posmatra se na osnovu udela preduzeća koja koriste integralni poslovni software (Enterprise Recource Planning - ERP), software za upravljanje odnosima sa klijentima (Customer Relationship Management-CRM) i software za upravljanje lancem snabdevanja (Supply Chain Management SCM). ERP software integriše sva odeljenja i funkcije kroz jedinstveni IT sistem (ili integrisani set IT sistema) u cilju omogućavanja donošenja odluka, obuhvatajući sve poslovne operacije (Zečević, 2015).

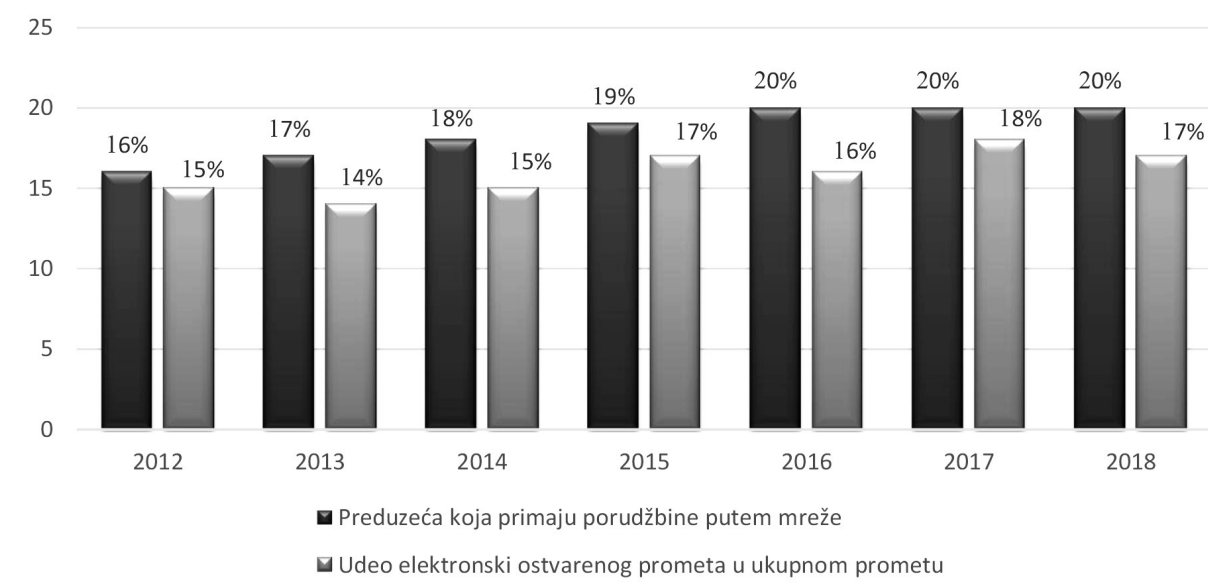

Slika 5 Udeo preduzeća koja primaju porudžbine putem mreže i udeo ostvarenog prometa u ukupnom prometu, EU-28, 2012-2018. (\% preduzeća) 
CRM software obuhvata odnose sa potrošačima, olakšava komunikaciju i poslovanje i unapređuje prodaju kroz praćenje i nadgledanje potrošača. SCM software upravlja informacijama u lancu snabdevanja kako bi se poboljšalo snabdevanje i bolje zadovoljile potrebe potrošača. Primena ovih software-a pokazatelj je stepena integrisanosti elektronskog poslovanja $\mathrm{u}$ preduzećima.

Posmatrano na nivou EU-28, 2017. godine 34\% preduzeća koristilo je ERP integralni poslovni software, CRM software-ske aplikacije koristilo je 33\% preduzeća a 18\% preduzeća je stvorilo preduslove za integrisanje sa kupcima i upravljanje lancem snabdevanja kroz SCM software-ske aplikacije. S obzirom na to da za korišćenje CRM i SCM software-a u Bazi podataka Eurostat-a postoje samo podaci za 2017. (Slika 6), gde je prikazan jedino procenat preduzeća koja koriste ERP software-e u periodu 2012-2017.

Po korišćenju ERP software-a, očekivano, ističu se velike razvijene evropske ekonomije Nemačka (38\%), Francuska (38\%), Italija (37\%), Španija $(46 \%$ preduzeća), a svoje poslovanje korišćenjem ERP software-a integrisala su i preduzeća u nekim manjim zemljama kao što su Grčka (37\%) i Slovačka (31\%), koje se nisu isticale po vrednosti ostalih posmatranih indikatora. Mađarska (14\%), Rumunija (17\%), Bugarska (23\%), Poljska (26\%) i Island (14\%) imaju nešto niži udeo preduzeća koja koriste ERP software.
U pogledu korišćenja CRM software-a prednjače Nemačka (46\% preduzeća) i Austrija (43\%) kao i zemlje Beneluksa - Belgija (42\%), Holandija (46\%) i Luksemburg (39\%), dok su CRM software-e tek krenule da uvode Rumunija (13\%), Letonija (15\%), Mađarska $(13 \%)$, Bugarska i Češka (18\%). Slično je i sa primenom SCM software-a, gde prednjače Nemačka (30\%), Belgija (26\%), Finska (22\%), Litvanija (28\%), dok su Mađarska (9\%), Rumunija (7\%) i Letonija $(6 \%)$ na začelju po korišćenju SCM software-a.

\section{ZAKLJUČAK}

Istraživanje je potvrdilo hipotezu od koje se pošlo $\mathrm{u}$ istraživanju - da razlike koje postoje među zemljama članicama imaju uticaja na dostignut nivo $\mathrm{u}$ usvajanju i primeni IKT $\mathrm{u}$ preduzećima u zemljama EU. Poredeći vrednosti pokazatelja primene IKT, s jedne strane, i karakteristike zemalja, s druge strane, identifikovali smo četiri faktora od uticaja na primenu IKT u preduzećima: regionalni položaj, geografske karakteristike, veličina zemlje, i dostignut nivo ekonomske razvijenosti. Regionalni položaj zemalja određuje blizinu velikih tržišta i utiče na način komunikacije preduzeća sa potrošačima. Geografske karakteristike mogu delovati podsticajno na usvajanje i primenu informacionih tehnologija u poslovanju preduzeća. Regionalni položaj i

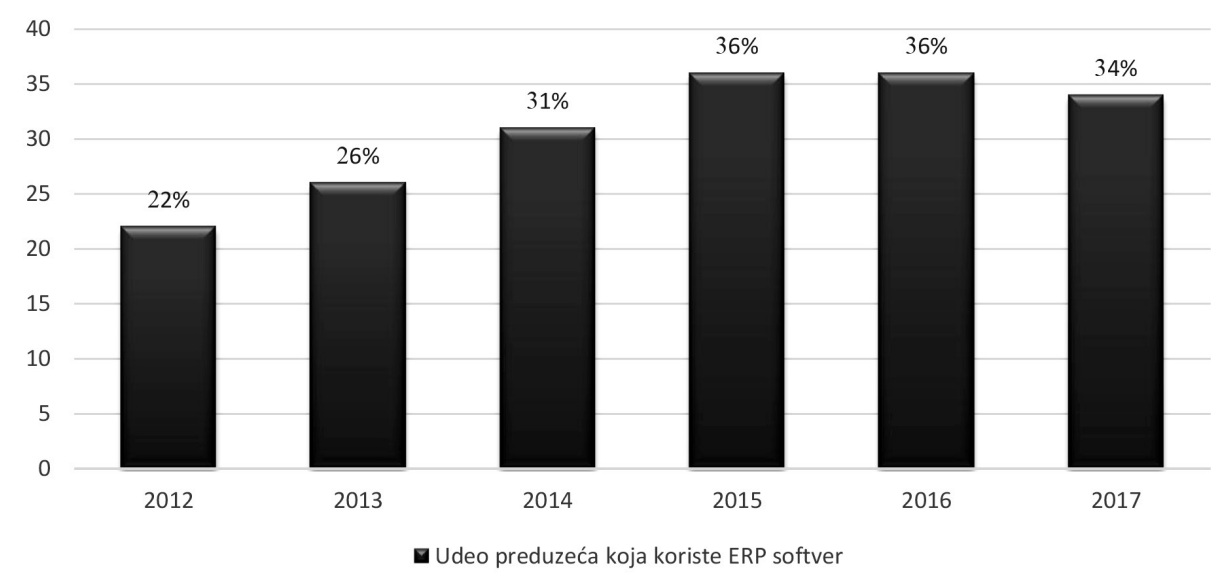

Slika 6 Korišćenje ERP software-a, EU-28, 2012-2017. (\% preduzeća) 
geografske karakteristike u nekim slučajevima mogu biti ograničavajući faktori, i to onda kada otežavaju razvoj IKT infrastrukture. Veličina zemlje, takođe, je bitna, ali ne onako kako bi se moglo očekivati, u smislu da velike razvijene ekonomije postižu najbolje performanse $\mathrm{u}$ primeni IKT. Naprotiv, male, dinamične ekonomije Evrope $u$ primeni IKT vide svoje razvojne šanse i često po vrednosti indikatora primene IKT prevazilaze velike razvijene ekonomije. Dostignut nivo ekonomskog razvoja je značajan zbog investicija u informacione tehnologije, razvoja informatičke poslovne kulture i spremnosti zemalja da prihvate informaciono-komunikacione tehnologije. Nivo razvijenosti utiče i na prihvaćenost naprednih informacionih tehnologija, kao što je cloud računarstvo i integrisanost elektronskog poslovanja u preduzećima. Neophodna su dodatna istraživanja radi detaljnije specifikacije uticaja ova četiri faktora, ali i eventualnog identifikovanja i drugih faktora koji utču na primenu informaciono-komunikacionih tehnologija u preduzećima.

Regionalna podela zemalja koja se sreće u literaturi (istok/zapad, sever/jug), u velikoj meri odražava specifičnosti zemalja i razlike među njima, ali je potrebno da bude više profilisana i trebalo bi da bude dopunjena analizom geografskih karakteristika zemalja. Ima, dakle, mnogo prostora za istraživanje, jer regionalna uopštavanja koja su osnov za podelu među zemljama često nisu dovoljna da bi se napravile razlike među zemljama. Regionalno grupisanje zemalja potrebno je dodatno produbiti geografskim karakteristikama i dostignutim nivoom razvijenosti. Moguće je specifično grupisanje zemalja prema određenim geografskim karakteristikama (na primer, ostrvske zemlje), ili prema tome kako dele zajedničku ekonomsku istoriju (zemlje Centralne i Istočne Evrope, bivše zemlje $u$ tranziciji), i ekonomskopolitičke interese (zemlje Beneluksa, skandinavske zemlje). Potrebna je detaljnija analiza koja bi više istražila i uvažila geografske specifičnosti zemalja.

Nivo ekonomske razvijenost zemalja je u vezi sa nivoom razvijenosti informatičke infrastrukture i investicijama u IKT. Informatička infrastruktura je osnova svake primene IKT, pa tako, zemlje koje imaju niske pokazatelje razvijenosti infrastrukture često imaju niske i ostale pokazatelje prihvaćenosti IKT. Pojedine zemlje se ipak trude da to svoje ograničenje u razvoju infrastrukture prevaziđu. To je, na primer, slučaj sa nekim ostrvskim zemljama, čija preduzeća uspevaju da komuniciraju sa potrošačima putem IKT i da uspešno integrišu IKT u svoje poslovanje. Takođe, u pojedinim zemljama Centralne i Istočne Evrope, preduzeća, uprkos skromnim infrastrukturnim kapacitetima, nastoje da održe brzinu konekcije iznad proseka i da iskoriste ono sa čim raspolažu. U nekim slučajevima, ograničenja u razvoju infrastrukture se ne mogu prevazići, pa se niska vrednost pokazatelja naprednih tehnologija - korišćenje usluga cloud računarstva i elektronske trgovine zapaža kod zemalja koje imaju niže pokazatelje razvijenosti informatičke infrastrukture.

Zemlje Beneluksa: Belgija, Holandija i Luksemburg, usvojile su nove, na elektronskom poslovanju zasnovane modele poslovanja i komuniciranja sa potrošačima i prednjače gotovo po svim posmatranim indikatorima. Slično je i sa Skandinavskim zemljama, koje su iznad evropskog proseka po gotovo svim posmatranim indikatorima. Preduzeća u malim državama EU i ostrvskim zemljama prednjače $u$ korišćenju društvenih medija, dok u zemljama Centralne i Istočne Evrope korišćenje društvenih mreža i društvenih medija još uvek nije postalo sastavni deo poslovanja. Što se tiče korišćenja ERP, SCM i CRM software-a u preduzećima, njihovo korišćenje je još uvek neujednačeno po zemljama. Ovo su tehnologije i načini komuniciranja sa potrošačima koje su preduzeća tek počela da usvajaju, kako u malim, tako i u velikim evropskim ekonomijama.

\section{REFERENCE}

Becker, J., Becker, A., Sulikowski, P., \& Zdziebko, T. (2018). ANP-based analysis of ICT usage in Central European enterprises. Paper presented at the 22nd International Conference on Knowledge-Based and Intelligent Information, \& Engineering Systems. Procedia Computer Science, 126, 2173-2183. doi.org/10.1016/j.procs.2018.07.231 
Bouwman, H., van der Hooff, B., van der Wijngaert, L., \& van Dijk, J. (2005). Information and Communication Technology in Organizations: Adoption, Implementation, Use and Effects. Amsterdam, NI: Boom.

Chroneos-Krasavac, B., Soldic Aleksic, J., \& Petkovic, G. (2016). The big data phenomenon: The business and public impact. Industrija 44(2), 117-144. doi:10.5937/ industrija44-10036

European Commission. (2017). Europe's Digital Progress Report 2017. Brussels, 10.5.2017 SWD 160 final. Retrieved March 17, 2019, from htt://ec.europa.eu/digital-singlemarket/en/news/europes-digital-progress-report-2017

European Commission. (2019). Digital Economy and Society Index Report 2019 Connectivity. Retrieved May 14, 2019, from http://ec.europa.eu/digital-single-market/en/news/ digital-economy-and-society-index-desi-2019

Eurostat. (2018). ICT usage and e-commerce in enterprises, Methodological Manual for statistics on the Information Society. Retrieved April 05, 2019, from http://circabc. europa.eu/faces/jsp/extension/wai/navigation/container. jsp

Real, J. C., Leal, A., \& Roldán, J. L. (2006). Information technology as a determinant oforganizational learning and technological distinctive competencies. Industrial Marketing Management, 35, 505-521. doi:10.1016/j. indmarman.2005.05.004

Roztocki, N., \& Weistroffer, H. R. (2008). Information Technology in Transition Economies. Journal of Global Information Technology Management, 11(4), 2-9. doi:10.1080 /1097198x.2008.10856476

Roztocki, N., \& Weistroffer, H. R. (2015). Information and Communication Technology in Transition Economies: An Assessment of Research Trends. Information Technology for Development, 21(3), 330-364.

Roztocki, N., Soja, P., \& Weistroffer, H. R. (2019). The role of information and communication technologies in socioeconomic development: Towards a multidimensional framework. Information Technology for Development, 25(2), 171-183. doi.org/10.1080/02681102.2019 .1596654
Soja, P., \& Cunha, P. R. (2015). ICT in transition economies: Narrowing the research gap to developed countries. Information Technology for Development, 21(3), 323-329. doi/ full/10.1080/02681102.2015.1028734

Soldić Aleksić, J., \& Stankić, R. (2015). A comparative analysis of Serbia and the EU member states in the context of networked readiness index values. Economic Annals, 60(206), 45-86. doi:10.2298/eka1506045S

Stankić, R., \& Stojković, D. (2017). The use of information and communication technologies in the business operations of Serbian enterprises. Ekonomske ideje i praksa, 27. doi:10.5937/EKOPRE1706393Z

Stankic, R., Jovanovic Gavrilovic, B., \& Soldic Aleksic, J. (2018). Information and communication technologies in education as a stimulus to economic development. Economic Horizons, 20(1), 59-71, doi:10.5937/ ekonhor1801061S

United Nation. (2018). Measuring the Information Society Report 2017 Volume 2. ICT country profiles. Retrieved May 17, 2019, from https://www.itu.int/en/ITU-D/Statistics/ Documents/publications/misr2017/MISR2017_Volume2. pdf

World Economic Forum. (2016). The Global Information Technology Report 2016. Retrieved April 20, 2019, from http://www3.weforum.org/docs/GITR2016/WEF_GITR_ Full_Report.pdf

Zečević, A. (2015.) Baze podataka u poslovanju. Beograd, RS: Zadužbina Andrejević.

Zečević, A., \& Radović Stojanović, J. (2017). The Use of Information and Communication Technologies in Enterprises in Serbia. Ekonomika preduzeća, 45(5-6), 393403. doi:10.5937/ekopre1706393z

Zečević, A., \& Radović Stojanović, J. (2018). The Use of Information and Communication Technologies in Enterprises in the Region: Level Achieved and Further Development. In S. Drezgić, S. Živković, \& M. Tomljanović (Eds.). Economics of Digital Transformation (pp. 177-194). Rijeka, Croatia: University of Rijeka, Faculty of Economics and Business in Rijeka. 
Primljeno 7. avgusta 2019, nakon revizije, prihvaćeno za publikovanje 23. decembra 2019. Elektronska verzija objavljena 25. decembra 2019.

Aleksandra Zečević je vanredni profesor na Ekonomskom fakultetu Univerziteta u Beogradu, na kojem je i doktorirala. Nastavnik je na nastavnim predmetima Baze podataka, Programski jezici, Nove informacione tehnologije, na osnovnim i master studijama. Naučne oblasti kojima se bavi su: baze podataka, programiranje, i elektronsko poslovanje.

Jelena Radović-Stojanović je docent na Kriminalističko-policijskom univerzitetu u Beogradu. Doktorirala je na Ekonomskom fakultetu Univerziteta u Beogradu. Predaje nastavne predmete: Osnovi ekonomije, Javne finansije i Informacioni sistemi u ekonomiji. Istraživačke oblasti njenog interesovanja su makroekonomija i ekonomska politika, ekonomska statistika, i poslovna informatika.

Aleksandar Čudan je vanredni profesor na Kriminalističko-policijskom univerzitetu u Beogradu. Doktorirao je na Ekonomskom fakultetu u Subotici, Univerziteta u Novom Sadu. Nastavnik je na nastavnim predmetima: Ekonomski kriminal, Menadžment informacionih sistema i Informacioni sistemi u ekonomiji. 


\section{PRILOG}

Tabela 1 Indikatori primene IKT u preduzećima (\% preduzeća), EU-28, 2017-2018.

\begin{tabular}{|c|c|c|c|c|c|c|c|c|c|c|}
\hline $\begin{array}{l}\text { zemlja/ } \\
\text { indikator }\end{array}$ & $\begin{array}{l}\text { Preduzeća } \\
\text { koja koriste } \\
\text { DSL ili neku } \\
\text { drugu fiksnu } \\
\text { široko-pojasnu } \\
\text { konekciiju } \\
\text { (2018) }\end{array}$ & $\begin{array}{l}\text { Preduzeća } \\
\text { koja poseduju } \\
\text { veb-sajt (2018) }\end{array}$ & $\begin{array}{l}\text { Preduzeća } \\
\text { koja koriste } \\
\text { bilo koji } \\
\text { društveni } \\
\text { medij (2017) }\end{array}$ & $\begin{array}{l}\text { Korišćenje } \\
\text { društvenih } \\
\text { mreža (2017) }\end{array}$ & $\begin{array}{l}\text { Kupovina } \\
\text { usluga u } \\
\text { domenu cloud } \\
\text { računarstva } \\
\text { (2018) }\end{array}$ & $\begin{array}{l}\text { Preduzeća } \\
\text { koja su primila } \\
\text { narudžbine } \\
\text { putem } \\
\text { računarskih } \\
\text { mreža (2018) }\end{array}$ & $\begin{array}{l}\text { Ukupan } \\
\text { promet } \\
\text { preduzeća } \\
\text { od e-trgovine } \\
\text { (2018) }\end{array}$ & $\begin{array}{l}\text { Preduzeća } \\
\text { koja imaju ERP } \\
\text { softver (2017) }\end{array}$ & $\begin{array}{l}\text { Preduzeća } \\
\text { koja koriste } \\
\text { softver za } \\
\text { upravljanje } \\
\text { odnosima } \\
\text { sa klijentima } \\
(\text { CRM })(2017)\end{array}$ & $\begin{array}{l}\text { Preduzeća } \\
\text { koja koriste } \\
\text { softver za } \\
\text { upravljanje } \\
\text { lancem } \\
\text { snabdevanja } \\
(\mathrm{SCM})(2017)\end{array}$ \\
\hline $\begin{array}{l}\text { Austrija } \\
\text { Belgija }\end{array}$ & $\begin{array}{l}90 \\
96\end{array}$ & $\begin{array}{l}88 \\
84\end{array}$ & $\begin{array}{l}53 \\
58\end{array}$ & $\begin{array}{l}51 \\
57\end{array}$ & $\begin{array}{l}23 \\
40\end{array}$ & $\begin{array}{l}18 \\
30\end{array}$ & $\begin{array}{l}14 \\
32\end{array}$ & $\begin{array}{l}40 \\
54\end{array}$ & $\begin{array}{l}43 \\
42\end{array}$ & $\begin{array}{l}16 \\
26\end{array}$ \\
\hline Bugarska & 84 & 51 & 34 & 34 & 8 & 8 & 5 & 23 & 18 & 17 \\
\hline Česka & 97 & 83 & $\begin{array}{l}36 \\
68\end{array}$ & 34 & 26 & 25 & 29 & 28 & 18 & 12 \\
\hline $\begin{array}{l}\text { Danska } \\
\text { Estonija }\end{array}$ & $\begin{array}{l}100 \\
98\end{array}$ & $\begin{array}{l}96 \\
78\end{array}$ & $\begin{array}{l}68 \\
40\end{array}$ & $\begin{array}{l}67 \\
39\end{array}$ & $\begin{array}{l}56 \\
34\end{array}$ & $\begin{array}{l}32 \\
20\end{array}$ & $\begin{array}{l}23 \\
15\end{array}$ & 40 & 36 & 23 \\
\hline Finska & 97 & 96 & 63 & 61 & $\begin{array}{l}34 \\
65\end{array}$ & 24 & 21 & 39 & 37 & 22 \\
\hline Francuska & 94 & 69 & 41 & 39 & 19 & 19 & 22 & 38 & 27 & 13 \\
\hline $\begin{array}{l}\text { Grckka } \\
\text { Holandija }\end{array}$ & $\begin{array}{l}04 \\
99\end{array}$ & $\begin{array}{l}65 \\
94\end{array}$ & $\begin{array}{l}50 \\
68\end{array}$ & $\begin{array}{l}49 \\
66\end{array}$ & $\begin{array}{l}13 \\
48\end{array}$ & $\begin{array}{l}12 \\
27\end{array}$ & $\begin{array}{c}4 \\
15\end{array}$ & $\begin{array}{l}37 \\
48\end{array}$ & $\begin{array}{l}18 \\
46\end{array}$ & $\begin{array}{l}10 \\
19\end{array}$ \\
\hline Hrvatska & 92 & 73 & 45 & 41 & 31 & 18 & 12 & 26 & $\begin{array}{l}40 \\
19\end{array}$ & 19 \\
\hline Irska & 93 & 79 & 68 & 67 & 45 & 35 & 35 & 28 & 31 & 12 \\
\hline $\begin{array}{l}\text { Italija } \\
\text { Kinar }\end{array}$ & 91 & 71 & 44 & 42 & 23 & 14 & 11 & 37 & 29 & 11 \\
\hline $\begin{array}{l}\text { Kipar } \\
\text { Letonija }\end{array}$ & $\begin{array}{l}94 \\
81\end{array}$ & $\begin{array}{l}71 \\
63\end{array}$ & $\begin{array}{l}67 \\
30\end{array}$ & $\begin{array}{l}65 \\
29\end{array}$ & $\begin{array}{l}27 \\
15\end{array}$ & $\begin{array}{l}14 \\
13\end{array}$ & 4 & 35 & 42 & 17 \\
\hline Litvanija & 96 & 78 & 50 & 47 & $\begin{array}{l}15 \\
23\end{array}$ & 22 & $\begin{array}{l}0 \\
13\end{array}$ & $\begin{array}{l}25 \\
47\end{array}$ & $\begin{array}{l}15 \\
33\end{array}$ & $\begin{array}{l}0 \\
28\end{array}$ \\
\hline Luksemburg & 97 & 83 & 54 & 52 & 25 & 16 & 15 & 41 & 39 & 18 \\
\hline Mađarska & 83 & $\begin{array}{l}66 \\
82\end{array}$ & 38 & $\begin{array}{l}36 \\
73\end{array}$ & $\begin{array}{l}18 \\
37\end{array}$ & 15 & 23 & 14 & 13 & 9 \\
\hline Nemačka & 93 & 87 & 45 & 40 & 22 & 22 & 14 & 38 & 46 & 30 \\
\hline $\begin{array}{l}\text { Poljska } \\
\text { Portija }\end{array}$ & 87 & 67 & 27 & 26 & 11 & 14 & $\begin{array}{l}15 \\
18\end{array}$ & 26 & 23 & 21 \\
\hline $\begin{array}{l}\text { Portugalija } \\
\text { Rumunija }\end{array}$ & $\begin{array}{l}96 \\
82\end{array}$ & $\begin{array}{l}63 \\
44\end{array}$ & $\begin{array}{l}46 \\
35\end{array}$ & $\begin{array}{l}45 \\
34\end{array}$ & $\begin{array}{l}25 \\
10\end{array}$ & $\begin{array}{c}19 \\
9\end{array}$ & $\begin{array}{c}18 \\
9\end{array}$ & $\begin{array}{l}40 \\
17\end{array}$ & 24 & 17 \\
\hline Slovačka & 89 & 76 & 39 & 35 & 21 & 16 & 21 & $\begin{array}{l}17 \\
31\end{array}$ & $\begin{array}{l}13 \\
22\end{array}$ & 15 \\
\hline Šlovenija & 99 & 84 & 47 & 45 & 26 & 25 & 17 & 30 & 25 & 15 \\
\hline Š́panija & 91 & 76 & 51 & 49 & 22 & 20 & 17 & 46 & 34 & 17 \\
\hline $\begin{array}{l}\text { Svedska } \\
\text { Uiedinieno }\end{array}$ & 93 & 92 & 65 & 63 & 57 & 32 & 24 & 31 & 34 & 13 \\
\hline Kraljevstvo & 93 & 82 & 63 & 60 & 42 & 22 & 19 & 19 & 31 & 12 \\
\hline
\end{tabular}

Izvor: Autori

Tabela 2 Rang preduzeća prema vrednosti indikatora primene IKT u preduzećima, EU-28, 2017-2018.

\begin{tabular}{|c|c|c|c|c|c|c|c|c|c|c|}
\hline $\begin{array}{c}\text { zemlja/ } \\
\text { indikator }\end{array}$ & $\begin{array}{l}\text { Preduzeća } \\
\text { koja koriste } \\
\text { DSL ili neku } \\
\text { drugu fiksnu } \\
\text { široko-pojasnu } \\
\text { konekciju } \\
(2018) \\
\end{array}$ & $\begin{array}{l}\text { Preduzeća } \\
\text { koja poseduju } \\
\text { veb-sajt (2018) }\end{array}$ & $\begin{array}{l}\text { Preduzeća } \\
\text { koja koriste } \\
\text { bilo koji } \\
\text { društveni } \\
\text { medij (2017) }\end{array}$ & $\begin{array}{l}\text { Korišćenje } \\
\text { društvenih } \\
\text { mreža (2017) }\end{array}$ & $\begin{array}{l}\text { Kupovina } \\
\text { usluga u } \\
\text { domenu cloud } \\
\text { računarstva } \\
(2018)\end{array}$ & $\begin{array}{l}\text { Preduzeća } \\
\text { koja su primila } \\
\text { narudžbine } \\
\text { putem } \\
\text { računarskih } \\
\text { mreža (2018) }\end{array}$ & $\begin{array}{l}\text { Ukupan } \\
\text { promet } \\
\text { preduzeća } \\
\text { od e-trgovine } \\
\text { (2018) }\end{array}$ & $\begin{array}{l}\text { Preduzeća } \\
\text { koja imaju ERP } \\
\text { softver (2017) }\end{array}$ & $\begin{array}{l}\text { Preduzeća } \\
\text { koja koriste } \\
\text { softver za } \\
\text { upravljanje } \\
\text { odnosima } \\
\text { sa klijentima } \\
\text { (CRM)(2017) }\end{array}$ & $\begin{array}{l}\text { Preduzeća } \\
\text { koja koriste } \\
\text { softver za } \\
\text { upravljanje } \\
\text { lancem } \\
\text { snabdevanja } \\
\text { (SCM) (2017) }\end{array}$ \\
\hline Austrija & 21 & 5 & 11 & 11 & 18 & 18 & 19 & 7 & 3 & 14 \\
\hline Belgija & 8 & 7 & 9 & 9 & 7 & 4 & 2 & 1 & 4 & 3 \\
\hline Bugarska & 24 & 27 & 26 & 26 & 28 & 28 & 25 & 25 & 23 & 10 \\
\hline Ceska & 5 & 9 & 24 & 24 & 12 & 6 & 3 & 19 & 24 & 20 \\
\hline Danska & 1 & 1 & 2 & 2 & 3 & 2 & 5 & 6 & 8 & 4 \\
\hline Estonija & 4 & 14 & 21 & 21 & 9 & 13 & 14 & 20 & 19 & 15 \\
\hline Finska & 7 & 2 & 7 & 7 & 1 & 8 & 9 & 9 & 7 & 5 \\
\hline Francuska & 11 & 21 & 20 & 20 & 22 & 15 & 7 & 11 & 15 & 18 \\
\hline Grčka & 25 & 24 & 13 & 13 & 25 & 26 & 26 & 12 & 25 & 25 \\
\hline Holandija & 2 & 3 & 4 & 4 & 4 & 5 & 16 & 2 & 2 & 8 \\
\hline Hrvatska & 18 & 18 & 18 & 18 & 10 & 17 & 21 & 22 & 22 & 7 \\
\hline Irska & 15 & 13 & 3 & 3 & 5 & 1 & 1 & 21 & 12 & 21 \\
\hline Italija & 20 & 19 & 19 & 19 & 16 & 22 & 22 & 13 & 14 & 23 \\
\hline Kipar & 12 & 20 & 5 & 5 & 11 & 23 & 27 & 14 & 5 & 12 \\
\hline Letonija & 28 & 25 & 27 & 27 & 24 & 25 & 24 & 24 & 26 & 28 \\
\hline Litvanija & 9 & 15 & 14 & 14 & 17 & 10 & 20 & 3 & 11 & 2 \\
\hline Luksemburg & 6 & 10 & 10 & 10 & 14 & 19 & 15 & 5 & 6 & 9 \\
\hline Mađarska & 26 & 23 & 23 & 23 & 23 & 21 & 6 & 28 & 27 & 26 \\
\hline Malta & 13 & 11 & 1 & 1 & 8 & 11 & 28 & 18 & 17 & 24 \\
\hline Nemačka & 14 & 6 & 17 & 17 & 19 & 9 & 18 & 10 & 1 & 1 \\
\hline Poljska & 23 & 22 & 28 & 28 & 26 & 24 & 17 & 23 & 20 & 6 \\
\hline Portugalija & 10 & 26 & 16 & 16 & 15 & 16 & 11 & 8 & 18 & 13 \\
\hline Rumunija & 27 & 28 & 25 & 25 & 27 & 27 & 23 & 27 & 28 & 27 \\
\hline Slovačka & 22 & 17 & 22 & 22 & 21 & 20 & 8 & 15 & 21 & 17 \\
\hline Slovenija & 3 & 8 & 15 & 15 & 13 & 7 & 13 & 17 & 16 & 16 \\
\hline Španija & 19 & 16 & 12 & 12 & 20 & 14 & 12 & 4 & 9 & 11 \\
\hline \multirow{2}{*}{$\begin{array}{l}\text { Švedska } \\
\text { Ujedinjeno } \\
\text { Kraljevstvo }\end{array}$} & 16 & 4 & 6 & 6 & 2 & 3 & 4 & 16 & 10 & 19 \\
\hline & 17 & 12 & 8 & 8 & 6 & 12 & 10 & 26 & 13 & 22 \\
\hline
\end{tabular}

Izvor: Autori 


\title{
THE USE OF INFORMATION AND COMMUNICATION TECHNOLOGIES BY ENTERPRISES IN THE EUROPEAN UNION MEMBER COUNTRIES
}

\author{
Aleksandra Zecevic', Jelena Radovic-Stojanovic² and Aleksandar Cudan² \\ 1Faculty of Economics, University of Belgrade, Belgrade, The Republic of Serbia \\ 2The Academy of Criminalistic and Police Studies, Department of Criminalistics, Belgrade, The \\ Republic of Serbia
}

\begin{abstract}
The paper analyzes the use of information and communication technologies (ICT) in enterprises in the European Union member states. The objectives of the analysis were to examine the level reached in the application of ICT in European enterprises and explore the differences in ICT usage that exist between the EU member states. The analysis is based on the Eurostat data on ICT usage in enterprises in the European Union countries (EU-28) for the years 2018 and 2017. The following indicators of ICT usage were analyzed: fixed broadband access, the speed of the internet connections, the presence of the Internet (enterprises having a website), the use of social media, the use of cloud computing services, e-commerce indicators (the share of the enterprises making e-sales and the share of e-commerce in the total turnover) and the indicators of e-business integration - the share of the enterprises using enterprise resource planning (ERP), customer relationship management (CRM) and the supply chain management (SCM) software applications. A comparative analysis of the EU countries by the value of these indicators was carried out. The main focus in the analysis was to identify the factors that influence the difference in the value of the ICT indicators between the countries. The analysis has shown that the regional position, the geographic characteristics, the size of the country and the level of its economic development are the factors that influence these differences.
\end{abstract}

Keywords: information and communication technology, e-commerce, e-business integration indicators, enterprises, European Union

JEL Classification: O330, L86 